\title{
8
}

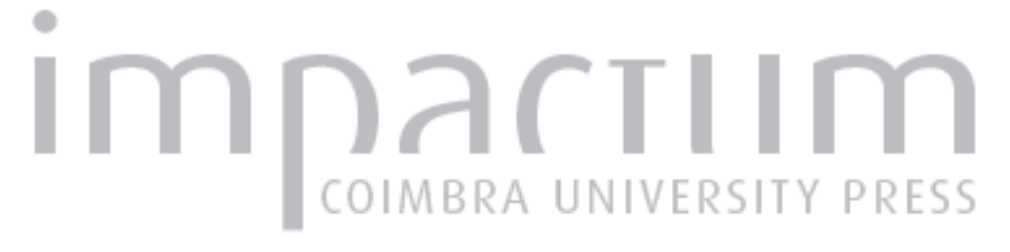

\section{Aluviões da Madeira: séculos XIX e XX}

Autor(es): Quintal, Raimundo

Publicado por: Associação Portuguesa de Riscos, Prevenção e Segurança

URL persistente:

URI:http://hdl.handle.net/10316.2/40121

DOI:

DOl:https://doi.org/10.14195/1647-7723_6_4

Accessed : $\quad$ 26-Apr-2023 13:56:25

A navegação consulta e descarregamento dos títulos inseridos nas Bibliotecas Digitais UC Digitalis, UC Pombalina e UC Impactum, pressupõem a aceitação plena e sem reservas dos Termos e Condições de Uso destas Bibliotecas Digitais, disponíveis em https://digitalis.uc.pt/pt-pt/termos.

Conforme exposto nos referidos Termos e Condições de Uso, o descarregamento de títulos de acesso restrito requer uma licença válida de autorização devendo o utilizador aceder ao(s) documento(s) a partir de um endereço de IP da instituição detentora da supramencionada licença.

Ao utilizador é apenas permitido o descarregamento para uso pessoal, pelo que o emprego do(s) título(s) descarregado(s) para outro fim, designadamente comercial, carece de autorização do respetivo autor ou editor da obra.

Na medida em que todas as obras da UC Digitalis se encontram protegidas pelo Código do Direito de Autor e Direitos Conexos e demais legislação aplicável, toda a cópia, parcial ou total, deste documento, nos casos em que é legalmente admitida, deverá conter ou fazer-se acompanhar por este aviso.

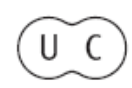




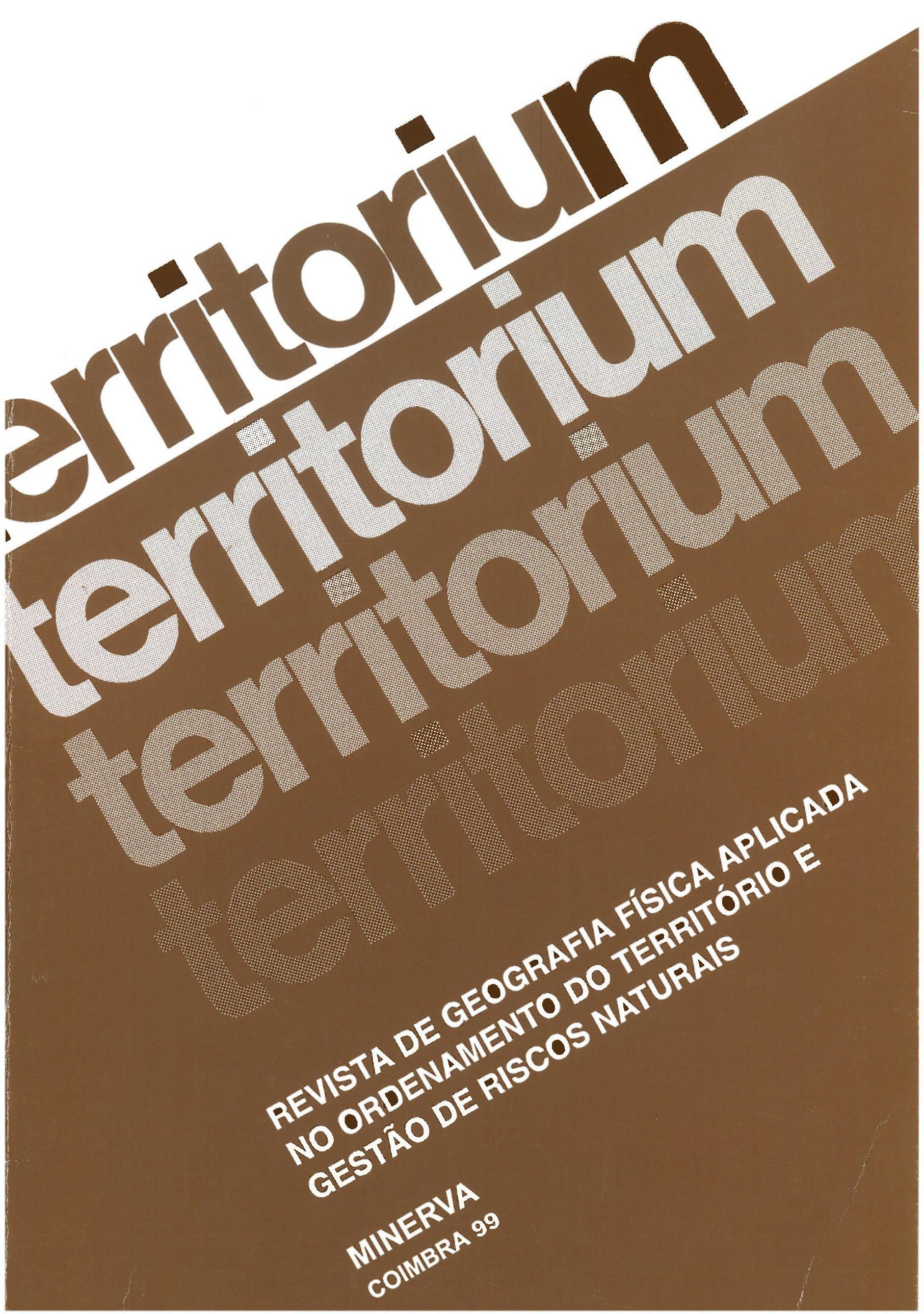




\title{
Aluviões da Madeira. Séculos XIX e XX
}

\author{
Raimundo Guintal *
}

Resumo:

As inundações catastróficas das ribeiras da Ilha da Madeira recebem o nome regional de aluviões. Neste artigo referem-se as mais importantes dos séculos XIX e XX e apresentam-se as condições atmosféricas que as originam. A análise das características de ocupação do solo que as favorecem leva à consideração de elementos que podem minimizar os seus efeitos.

Palavras chave:

Madeira, inundações rápidas, riscos.

\section{Résumé:}

Les inondations catastrophiques des rivières de l'île de Madère sont connues par le nom régional de "aluviões". On présente dans cet article les inondations rapides les plus importantes des XIXe XXe siècles, aussi bien que les conditions météorologiques qui sont à leur origine. L'analyse des caractéristiques de l'occupation des sols qui peuvent les favoriser conduisent à la consideration des elements qui peuvent minimiser ses effets.

Mots clés:

Madère, inondations rapides, risques.

\begin{abstract}
:
Catastrophic floods in Madeira Island are known by "aluviões". The aim of this article is to introduce the most important ones in the XIXth and XXth centuries as well as the atmospheric conditions in their origin. Analysing land use that makes easy their occurrence, it is possible to know some elements to minimize their effects.

Key words:

Madeira, flash floods, risks.
\end{abstract}

\section{0 significado do termo ALUVIÃO na Madeira}

Quando uma nuvem dotipocúmulo-nimbo provoca um violento aguaceiro sobre uma área restrita, ou quando uma tromba de água descarrega todo o seu conteúdo, geram-se de imediato fortes caudais capazes de arrastar volumosos detritos sólidos.

Árvores, blocos rochosos, terrenos agrícolas, tudo é arrancado e transportado pelas águas em correria louca vale abaixo até ao mar. Eis que o leito da ribeira se estreita ou um qualquer obstáculo se interpõe no caminho: a água abandona velozmente a secção que lhe tinham destinado e invade as casas, rouba-lhes os habitantes. Éa morte, a tragédia. Mais uma ALUVIÃO.

* Geógrafo. Vereador da Câmara Municipal do Funchal.
A História da Madeira está marcada de episódios sangrentos provocados pelas águas revoltas das ribeiras.

De todas as catástrofes que martirizaram os madeirenses, a maior foi a aluvião de 9 de Outubro de 1803. Segundo relatos da época, devem ter morrido devido à força bruta das águas cerca de 1000 pessoas, a maioria delas no Funchal. A cidade capital da Região Autónoma da Madeira naquela altura não teria sequer 25.000 habitantes!

Todos os anos, no dia 9 de Outubro, os madeirenses recordam a trágica data, participando, com larga adesão e profundo sentimento, na procissão solene do Senhor dos Milagres em Machico, outra das localidades martirizadas.

Uma situação meteorológica geradora dum temporal como o de 9 de Outubro de 1803 é perfeitamente possível em qualquer Outono ou Inverno. 
É verdade que hoje, graças aos poderosos instrumentos de previsão meteorológica, é possível avisar com alguma antecedência o aparecimento dum centro ciclónico muito cavado ou dum sistema frontal bastante activo.

Os avisos de alerta do Instituto de Meteorologia poderão desencadear medidas urgentes de evacuação das populações dos lugares mais perigosos, salvando-se vidas e preservando-se bens. No entanto, as acções preventivas de última hora não podem evitar o rápido aumento do caudal das ribeiras e o assalto a casas, armazéns ou terrenos agrícolas que ocupam os leitos de cheia. Não poderão impedir, também, uma intensa acçãoerosiva se as bacias de recepçãoestiverem descobertas de vegetação.

Após as cheias de 1803 foram construídas muralhas de encanamento das três ribeiras que atravessam o Funchal. Essas obras, superiormente dirigidas pelo brigadeiro Reinaldo Oudinot, revelaram-se de grande importância para a segurança da capital madeirense mas não impediram em definitivo que a água das ribeiras deixasse de invadir as ruas.

A última vez que as águas galgaram os muros das ribeiras e arrasaram a capital madeirense foi na noite de 29 de Outubro de 1993. Ruas esburacadas, muros derrubados, carros arrastados para o mar, casas destruídas e nove mortos, foram as consequências imediatas de mais uma ALUVIÃO.

\section{As Aluviões que ocorreram desde o princípio do Século XIX até à actualidade}

Desde o princípio do século XIX até ao final de 1998 ocorreram 30 aluviões. Este número poderá sofrer ligeiras correcções com o aprofundamento da investigação. Um aspecto merecedor duma mais aturada reflexão e duma mais afinada definição é o que diz respeito ao carácter catastrófico da aluvião. Nesta primeira relação englobei as cheias que provocaram mortos ou, pelo menos, destruição significativa de habitações, armazéns, pontes, estradas e terrenos agrícolas.

9 de Outubro de 1803. - Na noite de 9 de Outubro de 1803 a Madeira sofreu a maior tragédia da sua história. As torrentes mortíferas deixaram marcas em toda a ilha, mas com maior intensidade no Funchal, Machico e Santa Cruz.

Uma testemunha que viveu esses momentos dramáticos, escreveu a 15 de Outubro de 1803 uma carta a D. Juan Estevan Fernandes, que vivia em Portugal continental, descrevendo os pormenores da calamidade. Para melhor aquilatarmos da dimensão do fenómeno, vamos transcrever as passagens mais significativas dessa missiva. ${ }^{(1)}$

(1) Diário de Notícias, Funchal, 9 de Outubro de 1917.

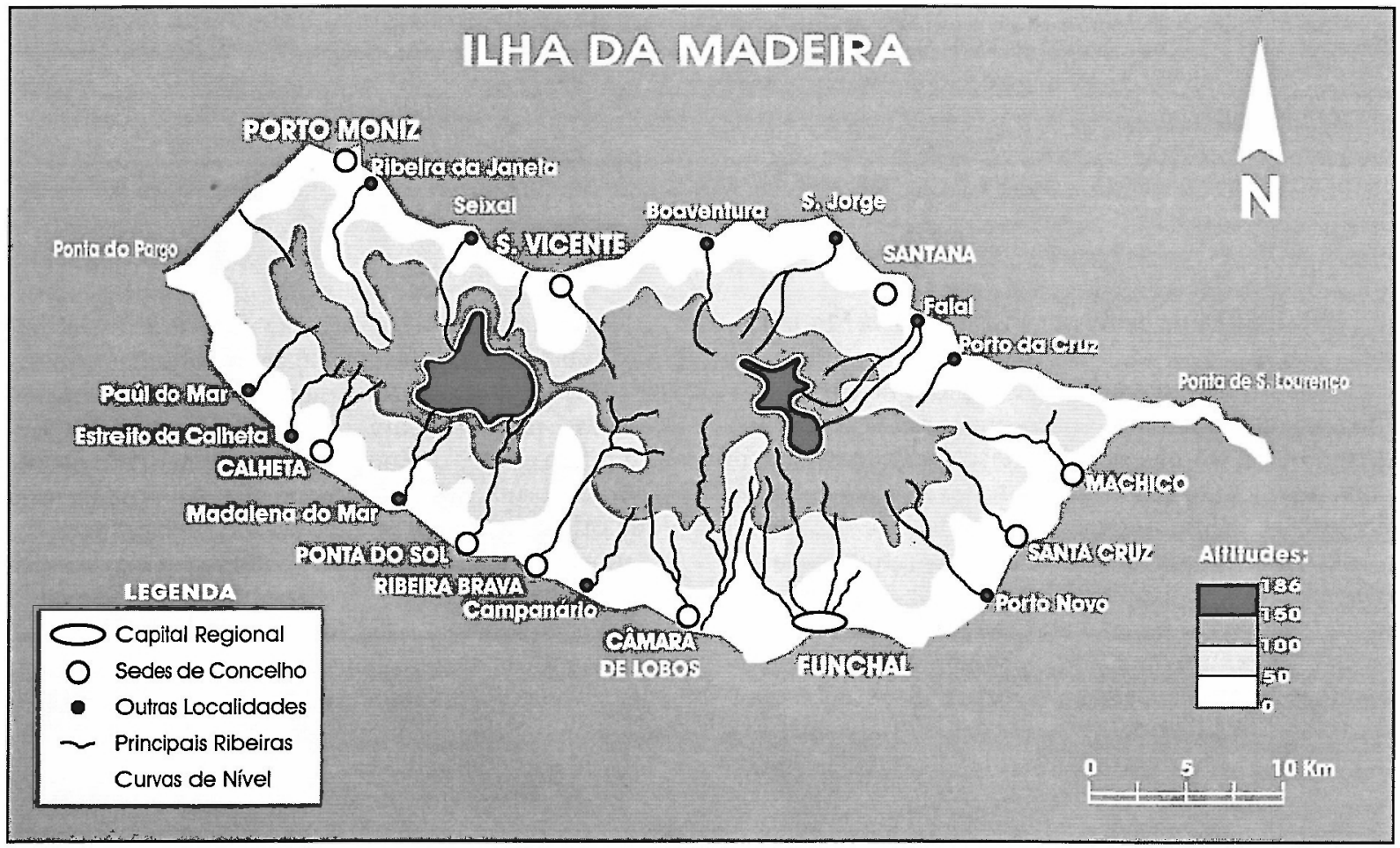

Mapa 1 - Madeira - relevo e ribeiras 
"Principiou a chover pelas dez horas da manhã moderadamente, continuou até às 8 da noite indo sempre a mais mas não sendo coisa que assustasse, e das 8 até às 8 e meia de repente cresceram as ribeiras de forma que não cabendo as águas por dentro das suas muralhas por causa das muitas e grandes árvores e disformes penedos que traziam arruinaram as muralhas pelos alicerces. A ribeira de Nossa Senhora do Calhau dividiu-se em 3 partes e uma rompeu a muralha da cidade por cima da Quinta chamada do Cascalho, deixando esta sem esperança de se poder mais cultivar e dali veio trazendo diante de si todas as fazendas e entrando na cidade no sítio do Ribeirinho onde entulhou todas as casas dos primeiros andares, todas as portas e escadas ficaram arruinadas porém as casas não caíram mas tudo o que tinha dentro perdeu-se.

(...) A ribeira da Praça principiou a entrar na cidade acima do recolhimento do Senhor Jesus e fez a este constante ruina e entrando pelas Ruas do Valverde todas as casas que ficavam para a parte da ribeira, levou ao mar e as ruas que atravessavam para a parte do Carmo as casas que não caíram ficaram entulhadas."

Segundo o autor da carta, entre as nove e as dez da noite, a enchente das três ribeiras arruinou uma grande parte da cidade.

"As pontes de São Paulo, Rua dos Ferreiros, da Praça e de Nossa Senhora do Calhau, foram abaixo. A Rua dos Tanoeiros, ponte da Rua Direita e perto de Nossa Senhora do Calhau e juntamente a Igreja, Cabouqueira Valverde, foi tudo arrasado e imensidade de povo morreu; são mais de mil os infelizes que pereceram, isto não é exagerado, pois eu creio que será muito mais, porque famílias inteiras desapareceram.

(...) Dizem que morreram na cidade 1000 pessoas, a este respeito o digo que nas igrejas se não podem já enterrar mais, ao mesmo tempo se metiam a 3 e 6 corpose alguns que ainda vão aparecendo no desentulho aí mesmo lhe botam alcatrão, e os queimam por não estarem em estado de se lhe bolir em razão o mau cheiro.

(...) O estrago é incalculável, pois, só de pipas de vinho se reputa a seis mil, além disso, muitos graneis com milho e armazéns com farinhas; o pior é que a cidade está agora ameaçando a sua total ruína, pois, como não tem defesa e estão as ribeiras muito entulhadas com grandes pedras, de forma que em muitas partes, estão mais altas que o nível da cidade; qualquer enchente que haja, o perigo é certo. Deus nos acuda.

O povo está tão atemorizado que, qualquer chuva que haja, fogem da cidade para onde as ribeiras não possam chegar muitas famílias têm emigrado para os campos. Machico e Santa Cruz também passaram pelo mesmo estrago.

(...) O prejuízo é incalculável em toda a ilha. Só em vinhos velhos perderam-se umas poucas de mil pipas; por quanto, a maior parte da cidade que foi ao mar e mais se inundou, era a que tinha mais lojas e armazéns.
O convento do Servo de Deus também foi ao mar. Dizem que escapou parte do refeitório e um pequeno celeiro; eu o queria ver, porém, não se podia passar a ribeira dos Socorridos sem perigo".

Uma outra carta datada de 17 de Outubro de 1803, possivelmente escrita por José Freire Monterroyo Mascarenhas, reproduzida em 1880 pelo Dr. Accurcio Garcia Ramos na obra intitulada "Ilha da Madeira", é também bastante esclarecedora quanto à dimensão das cheias das ribeiras que afectaram de forma particularmente violenta a cidade do Funchal e as vilas de Machico e Santa Cruz.

"Uma chuva tranquila e por intrervalos precedeu por espaço de doze dias, a fatal época de 9 de Outubro, dia em que a atmosfera, cheia de vapores eléctricos, anunciava aos tranquilos insulanos até então felizes, uma chuva ordinária, resultante da posição do vento, que soprava da parte SW e realizada por intervalos, mais ou menos abundante, desde as duas até às 6 horas da tarde. Pelas 7 horas a atmosfera, incendiada pelo fogo eléctrico, apenas deixava ouvir ao longe o estampido confuso dos trovões, interceptado pelo movimento dos grandes calhaus, que então rolavam com medonho estrondo nas três ribeiras, e que nas enchentes ordinárias poderiam servir de majestoso espectáculo ao filósofo observador. Continuando as chuvas até às oito e meia com mais actividade, senti então a casa da minha residência, uma das melhores da cidade pela sua situação local, os efeitos de uma próxima, horrível e medonha tempestade. Os alicerces do edifício sofriam fortes concussões: a matéria eléctrica, fulminando, esclarecia, sem cessar, a vasta circunferência das montanhas, fazendo ver as torrentes que, impelidas por um vento impetuoso, formaram nas altas serranias da ilha a imensa quantidade de água que causou a triste e infeliz catástrofe observada no dia 10.

Cinco pontes de cantaria e alvenaria desapareceram; e o resto se acha ameaçado da última ruína. Altas e fortes muralhas, feitas de pedra e cal pelas margens oriental e ocidental das três ribeiras para segurança da cidade, foram demolidas ou sepultadas: seus antigos álveos, aumentados do quintuplo das suas respectivas e antigas larguras, excedem ao nível do pavimento da cidade por serranias de pedras enormes e entulho, que ameaçam o resto da mais funesta sorte. Ruas inteiras desapareceram com os seus habitantes; e outras, inundadas de água e lama, deixaram os proprietários e inquilinos reduzidos à última indigência.

Uma grande parte da freguesia de Santa Maria Maior, assim como a sua igreja, a mais antiga da cidade, não existe, com uma grande parte dos seus infelizes moradores; e o resto disperso cáe lá, inundado, e abandonado, oferece aos olhos do homem sensível um objecto de dor, de ruína e de consternação. 
As ruas chamadas Direita, Tanoeiros, Valverde, Santa Maria, Hospital Velho, e outras, foram ao mar, com uma incrível multidão de seus habitadores, levando consigo em todos os géneros de víveres e fazendas um cabedal incalculável; imensas propriedades rurais, estufas cheias de vinhos velhos, armazéns, e graneis cheios de milho e trigo, lojas com farinhas e outros diversos géneros, e quintas, casas de lavradores, choupanas, gados, lagares e muitos outros estabelecimentos, que existiam nas margens das ribeiras e mesmo em distâncias consideráveis, ou nos subúrbios da cidade, tudo foi ao mar, com uma grande parte dos seus habitantes.

A vila de Santa Cruz, três léguas a leste da capital, foi aterrada e inundada, com a morte de muitas pessoase a ruína de alguns edifícios. A vila de Machico, cinco léguas a leste do Funchal, desapareceu, com uma parte dos seus infelizes habitadores. No lugar da Ribeira Brava, três léguas a oeste da cidade, foram ao mar algumas propriedades rurais, choupanas e famílias. A freguesia do Campanário, duas léguas a oeste, sofreu perdas imensas pelas propriedades rurais, que foram ao mar com a morte de alguns colonos. Todos os vinhos que se achavam nos armazéns das vilas, margens das ribeiras, e portos marítimos desapareceram. E finalmente todos os sítios da ilha sofreram mais ou menos perdas tão consideráveis, que os séculos futuros jamais poderão recuperar."(2)

Da leitura dos dois textos deduz-se que na origem de tão grande tragédia esteve uma situação atmosférica caracterizada pela existência de vento de SW, trovoadas e forte precipitação. A calvície das montanhas sobranceiras ao Funchal, bem visível nas gravuras da época, e a falta de encanamento das ribeiras dentro das áreas urbanas, funcionaram como causas para o agravamento da catástrofe.

$\mathrm{Na}$ sequência desta aluvião chegou à Madeira, em Fevereiro de 1804, o brigadeiro Reinaldo Oudinot com o objectivo de orientar a construção e reparação das muralhas das três ribeiras que atravessam o Funchal.

"EmDezembro de 1806, comunicava ele ao governo central que, apesar dos grandes temporais e fortes invernias que pouco antes houvera, as muralhas tinham resistido ao embate violento das águas e oferecido uma prova evidente da solidez da sua construção"."(3)

Mas, não obstante a enorme importância destas obras públicas, as águas voltaram a invadir as ruas do Funchal em Outubro de 1815.

30 de Outubro de 1815. - No centro do Funchal e na Rua de Santa Maria as lojas foram inundadas e

(2) Accurcio Garcia RAMOS, Tha da Madeira, Tomo II, Lisboa, 1880.

(3) Padre Fernando Augusto da SILVA e Carlos Azevedo de MENESES, Elucidário Madeirense, $3^{\mathrm{a}}$ edição, Funchal, 1965. sofreram enormes prejuízos. A agricultura foi arrasada em muitos locais e registaram-se dois mortos no Estreito de Câmara de Lobos.

Vejamos algumas das consequências descritas num documento elaborado pela Câmara do Funchal:

"O maior perigo é da Ponte do Torreão para cima onde, para a parte de Leste, apenas este ano se tinha começado uma pequena porção de muralha que inteiramente desapareceu, e por isso se perderam várias porções de terra cultivada, uma casa que de novo se tinha construído, e felizmente escapou a Ponte que pela sua incrível fortaleza resistiu a um impulso de água, que todos julgavam capaz de arrasar toda a Cidade: e por não se terem concluído as muralhas ou se principiarem pela parte oposta, ficaram quase todas arrasadas, sendo preciso para as desaterrar outro tanto cabedal quanto se gastou na sua construção. Duas pontes de pau, que estavam nesta Ribeira, uma chamada a Ponte de Pau do Torreão, e outra chamada a Ponte da Rua dos Ferreiros igualmente desapareceram no mesmo momento em que as águas correram com mais abundância: ficcou porém um pouco arruinada, mas em sofrível estado de se transitar por ela, outra ponte de pau, que nesta mesma Ribeira existe chamada a Ponte da Praça (...).

A última Ribeira que é a de Nossa Senhora do Calhau, por estarem inteiramente concluidas as suas muralhas não padeceu ruína alguma. Resta-nos, Senhor, os dois pequenos Ribeiros de que já fizémos menção, um dos quais corta pelo centro da Cidade, e o outro quase nos confins dela pelo sítio da Nora, na freguesia de Nossa Senhora do Calhau: tanto um como outro, por falta de muralhas que contivessem suas águas, fizeram inexplicáveis estragos. O primeiro rompeu a Rua da Laranjeira além da Igreja do Carmo para a parte de Leste, inundou toda aquela rua, e levou após de si imenso rochedo com que foi aterrada toda a Rua do Ribeirinho até ao Beco da Malta, e dali por aquele mesmo beco se comunicou ao Largo do Pelourinho, e por isso apesar de um grande cano por onde desembocaram as águas para o calhau chegaram neste lugar, que é um largo considerável a sete pés de altura, tendo estas ruínas de extensão desde a referida Rua da Laranjeira até aquele lugar para cima de cento e oitenta braças. Esta inesperada corrente por meio de uma Cidade que em todas as lojas das suas casas tem géneros de muito valor, pode por si mesma suscitar uma ideia do prejuízo que sofreram os seus habitantes.

Não foi menos considerável a perda ocasionada pelas águas do pequeno Ribeiro chamado da Nora, pois ainda que a Cidade neste ponto é por extremo estreita, por compreender só três ruas, e quatro ordens de casas, ele as inundou de tal forma, que arrombando as portas das lojas, e entrando pelas que estavam abertas, nada deixou em bom estado do que elas continham. A grande Rua de Santa Maria, que é 
limitada a Leste por uma elevada mas pequena ponte de pedra, por onde costumam passar as águas deste mesmo ribeiro, perdendo estas a direcção da dita ponte, e entranhando-se pela parte da mesma rua ficou inundada de tal forma, que tão bem subiu o depósito das águas a mais de cinco pés de altura, fazendo a todos um prejuízo incalculável, e muito principalmente aos Tendeiros que desgraçadamente perderam todos os géneros que tinham nas suas Tendas.

Os Lavradores, Senhor, ainda se lamentam mais da sua sorte do que os próprios Cidadãos: eles viram copiosas, e desconhecidas águas arrancar-Ihes pelas raízes os idosos troncos, e precipitar das altas montanhas as exímias penedias, que envolvidas com as mesmas águas arrasavam os vales, e faziam perder a maior parte da sua cultura. Os gados que se achavam dispersos em lugares mais eminentes, foram arrojados debaixo destas ruínas, e apesar da cautela que todos tomaram na salvação de suas vidas, ficaram algumas pessoas perigosamente feridas, além de dois rapazes que pereceram em um casal da Freguesia do Estreito de Câmara de Lobos, por ser incompatível com a violência das quebradas poder-se-lhes dar o menor socorro.

Cada um destes Lavradores julgando-se absolutamente desgraçado parece querer proferir imprecações contra a sua existência, e abandonar um País que tão ingrato se tem mostrado (...).'(4)

24 de Outubro de 1842. - Grande parte do Funchal foi inundado, muitas casas ficaram em ruínas.

"Em Outubro de 1842 foram também imensos os estragos, o terror e confusão gerais, e o espectáculo grandioso mas tristíssimo. Nada resistiu à espantosa força da água que se despenhava com a grande velocidade adquirida em solo tão declive. E o mar tempestuoso lançou à costa com vento sul vários navios que não puderam se pôr ao largo, perdendo-se assim a maior parte deles e algumas pessoas das tripulações.

De modo que essas ribeiras fundas e claras, tão próprias da paisagem que aformoseia a risonha ilha, que gemiam por entre a fresca sombra dos arvoredos inclinados para as beijar, mas cuja beleza mais consistia na graça do que na força com que arrastavam flores e palmas, agora cheias de estrondo e de grandeza volviam nas suas águas os cadávares dos antigos cedros quebrados pela fúria da sua cheia e a toda a parte levavam a devastação e o terror!'(5)

17 a 20 de Novembro de 1848. - No Funchal as ribeiras correram com violência, mas não saltaram as mural has. Muitos campos agrícolas foram destruídos no concelho de Santana, onde houve perdas de vidas humanas.

(4) Atlântico - revista de temas culturais, n. 3, Funchal, Outono de 1995.

(5) Accurcio Garcia RAMOS, Iha da Madeira, Tomo Il, Lisboa, 1880.
Pelas 19 horas do dia 17 começou "a cair uma copiosíssima chuva, que aturou até à meia noite; compreendeu cinco freguesias, distrito entre leste e norte; arruinou todas as estradas do litoral, levando muitas pontes; destruilu muitas casas e armazéns, no que pereceram oito pessoas"(6)

Os estragos desta aluvião foram relatados numa carta enviada ao ministério do reino pelo secretário geral, servindo de governador civil, Servulo Drummond de Meneses:

"Não foi igual a sua força em todos os pontos da ilha; mas em muitas freguesias, segundo as informações recebidas, correu com violência pelos vales maior volume de água do que no horroroso dia 24 de Outubro de 1842.

Na ribeira dos Socorridos, que divide o concelho do Funchal do de Câmara de Lobos, foi este facto bem verificado.

Felizmente a capital do distrito escapou desta vez à inundação e estragos, passando só pelos sustos que causaram as três grandes ribeiras que a retalham, as quais arrastaram com estrondo, em copiosa enchente, enormes pedras e ruínas dalgumas fazendas, que iam depositar impetuosamente no oceano a não pequena distância do seu limite ordinário.

Mas emalguns dos outros concelhos, principalmente no de Santana, as torrentes destruiram nos vales toda a cultura de inhame, estimado alimento dos Iavradores, levando com as terras essas e muitas outras benfeitorias produtivas e importantes; abateram uns quatroarmazéns de pedra e cal, algumas pontes e muralhas bem construídas; cortaram e tornaram intransitáveis muitas estradas; fizeram cair muitos socalcos, e causaram outras quebradas e ruínas; mataram alguns camponeses e deixaram na indigência muitas famílias". (7)

5 e 6 de Janeiro de 1856. - "Das duas para as três da tarde de cinco do corrente vento oeste-sudoeste começa de soprar rijamente; tolda-se de grossas nuvens o céu; espessas trevas envolvem a cidade; chuvas copiosas alagam as ruas; e repentinamente o bramir das ribeiras, que arrastam em sua corrente caudalosa volumosos penedos trazidos das montanhas, espalha em todo o Funchal a consternação e o terror.

Das dez para as onze horas da noite a ribeira denominada de João Gomes, consideravelmente entulhada, principiou a extrabordar junto à ponte da Praça Académica, a qual já muito dificilmente dava passagem às águas.

À meia noite a corrente havia levado os mainéis desta ponte, tornando-a intransitável.

(6) Revista Universal Lisbonense. 22 de Fevereiro de 1849.

(7) Sérvulo Drummond de MENESES e António Jacinto de FREITAS, Uma Época Administrativa da Madeira e Porto Santo, Funchal, 1850-52. 
Momentos depois já ela, completamente aterrada, era leito da ribeira, que se dividia, em torrentes, para os lados e para o mar.

Da uma para as duas horas da madrugada diminuiram as chuvas, e a sobredita ribeira entrou de enfraquecer.

Das três para as quatro horas, porém, tornaram a cair copiosas chuvas; a ribeira de João Gomes, a que me tenho referido, tomando de novo grosso volume de água, saiu do leito, em caudalosa torrente, para a rua do Anadia, inundou todas as casas e quintais da Rua do Ribeirinho de Baixo, pondo em risco a vida dos moradores, e indo de encontro ao Forte do Pelourinho, escalou parte das muralhas, abrindo passagem para o mar". (8)

Vários cidadãos "Iançaram barcos às ruas, para pelas janelas salvar tantos infelizes que se haviam conservado em casa". ${ }^{(9)}$

A Ribeira de Santa Luzia ficou entulhada mas não chegou a provocar estragos. A de São João provocou danos nas imediações da capela.

Em Câmara de Lobos, Ribeira Brava, Serra de Água, Tabua, Ponta do Sol, Madalena, Paul do Mar e São Vicente houve também grandes devastações produzidas pelas águas que desceram em fúria das montanhas.

14 e 15 de Março de 1856. - Ainda não refeitos do enorme trauma provocado pela aluvião de 5 de Janeiro, os madeirenses voltaram a viver horas de grande angústia.

"A chuva foi tão abundante e sem cessar, que assustou toda a povoação, principalmente aos habitantes das proximidades das ribeiras de João Gomes e Santa Luzia.

A ribeira de João Gomes, onde já se havia feito alguns trabalhos de desentulhamento, ficou completamente obstruída, saindo mais de uma vez as águas de seu leito, inundando parte da cidade. A ribeira de Santa Luzia sofreu novamente, e até à ponte do Bom Jesus carece de ser limpa.

Nenhuma desgraça temos a lamentar, porque a povoação dos sítios inundados começou a fugir, seriam três horas da tarde do dia 14.

$\mathrm{Na}$ freguesia da Ribeira Brava a ribeira arruinou quase toda a muralha que defende o lugar, levou parte da muralha, destruindo o cemitério, fazendo ir para o mar alguns dos cadávares que se achavam enterrados!

Os habitantes deste lugar estiveram dois dias no maior sobressalto e consternação.

No Arco da Calheta houve uma quebrada que levou catorze casais, e segundo nos dizem não morreu ninguém porque esses infelizes fugiram a tempo.

(8) Semanario Official, n. 87, 12 de Janeiro de 1856

(9) O Clamor Publico, n. 86, 7 de Janeiro de 1856.
A freguesia da Serra de Água também teve novos prejuízos."(10)

1 de Janeiro de 1876. - A Ribeira da Madalena foi a única que provocou prejuízos importantes. Não houve perda de vidas humanas.

2 e 3 de Outubro de 1895. - As inundações provocaram graves prejuízos na Calheta, Ribeira Brava e São Vicente. Alguns mortos, muitas casas soterradas, estradas e pontes destruídas. As ribeiras do Funchal trouxeram muita água mas não transbordaram.

O Diário de Notícias do Funchal relatou o temporal do seguinte modo:

- "As chuvas torrenciais da noite de 3 do corrente causaram graves prejuízos, principalmente na Calheta, Ribeira Brava e São Vicente, onde muitas famílias ficaram pedindo esmola, porque tudo quanto possuiam foi destruído pelas cheias.

Naquelas localidades, onde reinavam, dantes, a abundância e o bem-estar relativo, apresentam actualmente o mais triste e desolador espectáculo: casas soterradas, outras arrastadas para as ribeiras e praias, no enxurro das cheias; terrenos cultivados, que constituíam o único recurso de muitos infelizes lavradores, desapareceram totalmente; estradas obstruídas; pontes derrubadas; ruínas e destroços por toda a parte; grupos de famintos esfarrapados, expostos a todos os insultos do tempo, mendigando pelos caminhos atulhados de despojos da horrível catástrofe; e acrescente-se ainda a este quadro de anarquia e miséria - a perda de algumas vidas arrebatadas pela tempestade". (11)

29 de Novembro de 1901. - Inundações e desmoronamentos no Funchal e Machico.

"Em várias ruas da cidade a água subiu à altura de 3 palmos entrando em alguns estabelecimentos e trazendo parte de seu conteúdo para a rua.

Tem caído na vila de Machico chuvas torrenciais.

A Ribeira arrasou as pontes dos sítios da Ribeira Grande, Cales e Moinho da Serra e encaminhando-se para a Banda de Além, reinando grande pânico nos habitantes daquele sítio.

Uma quebrada aterrou uma casa no sítio da Ribeira de Machico, sucumbindo nove pessoas. A vila correu grande perigo pois continua sempre chovendo". ${ }^{(12)}$

25 e 26 de Fevereiro de 1920. - "Nestes dois dias fez-se sentir um violento temporal de vento e chuva que causou inúmeros prejuízos em toda a ilha. As ribeiras que atravessam a cidade, embora trouxessem muita água não chegaram a transbordar, mas houve inundações em vários sítios, devido à abundância

(10) O Clamor Publico, n. 97, 24 de Março de 1856.

(11) Diario de Notícias, Funchal, 10 de Outubro de 1895.

(12) A Cruz, Funchal, 1 de Dezembro de 1901. 
das chuvas e aos ribeiros da Nora, do Til e dos Louros terem ficado obstruídos. No bairro de Santa Maria chegaram a andar barcos nas ruas para conduzir pessoas de uns para outros pontos, e diz-se que em toda a ilha ficaram mais de 500 pessoas sem abrigo, sendo incalculáveis os destroços causados pelo vento Noroeste no arvoredo, nos canaviais e em muitas outras culturas.

A vila da Ribeira Brava correu grande risco de ser destruída pelas águas, tendo saído a imagem de São Bento em procissão e havendo depois preces na igreja paroquial.

Em Machico, Santa Cruz, São Vicente e Camacha registaram-se importantíssimos prejuízos, morrendo uma mulher e uma criança nesta última freguesia. Desapareceram, com os repectivos tripulantes, alguns barcos de pesca de Câmara de Lobos." ${ }^{(13)}$

5 e 6 de Março de 1921. - Choveu intensamente em toda a ilha, tendo-se verificado inundações e estragos na agricultura em Machico, Santana, Faial e São Jorge. Em Machico as águas subiram nalguns locais até quase ao primeiro andar das casas. $\mathrm{Na}$ Ribeira Brava morreram três crianças devido ao desmoronamento duma casa e outra criança sucumbiu arrastada pelas águas.

15 de Dezembro de 1926. - Um violento temporal provocou o naufrágio do iate "Physalia", que se encontrava fundeado na baía do Funchal, provocando a morte de 6 pessoas.

$O$ vento de Sul-Sudoeste, para além de ter determinado mar alteroso, impeliu as nuvens encosta acima, gerando fortes chuvadas. O caudal das ribeiras aumentou bastante e ao mar chegaram animais mortos e troncos de árvores.

6 de Março de 1929. - A Ribeira da Vargem, em São Vicente, ficou momentaneamente obstruída por pedras e terras duma derrocada. A represa rebentou e a água em turbilhão provocou 32 mortos no sítio da Vargem.

"A chuva começara há dias já, a sua infiltração lenta ia desagregando os torrões, amolocendo o sub-solo, lentamente, surdamente, sem que ninguém se apercebesse da formidável obra de destruição que se estava operando.

E a chuva continuava sempre caindo, mas ia-se metendo pelo chão abaixo, desagregando os torrões. Mas ao de cima, era uma festa verde. E ninguém podia imaginar que, sob essa promessa de abundância, estava uma tremenda, formidável ameaça de morte, que estava a condenação de tantas, tantas vidas.
E anteontem, num instante, num relâmpago, a obra destruidora consumou-se.

Começou a terra a mexer-se, a estrebuchar. Era o princípio da agonia de tantas vidas. E num rompante satânico, num formidável, indescritível rompante de violência, dá-se a estupenda derrocada. Despenha-se a terra em escantilhão, num ruído que é uma infernal trovoada que tudo abala, que tudo estremece e os terrenos, numa rapidez estupenda, resvalam num frenesi doido, uns sobre os outros e, enormes, formidáveis em seus ímpetos de destruição, esmagam dezenas de vidas humanas, arrastam, em trejeitos horripilantes, todos os animais que encontram no seu caminho de vertigem, reduzem a terra também, as casas, os palheiros, os currais, e tudo se associa à infernal derrocada que vem, no percurso dum quilómetro, arrastando tudo". ${ }^{(14)}$

2 e 3 de Outubro de 1931. - Entre as 7 e as 10 horas do dia 3, o Funchal esteve sob uma violenta trovoada e chuvas torrenciais, que provocaram inundações na cidade. Na Rua de Santa Maria a água atingiu $75 \mathrm{~cm}$ de altura, tendo os bombeiros usado uma canoa para transportar os residentes. No Largo das Fontes a água subiu $1,5 \mathrm{~m}$. Algumas ruas estiveram transformadas em ribeiros. O caudal das ribeiras subiu bastante mas não invadiu as ruas marginais.

30 de Dezembro de 1939. - Na Madalena do Mar a ribeira destruiu cerca de 40 casas, arrastou terrenos de cultura e matou 4 pessoas.

Em Agosto de 1932 houve um grande desmoronamento de rochas na vertente esquerda da ribeira da Madalena. O vale em garganta ficou obstruído numa secção entre o sítio dos Chiqueiros, na freguesia dos Canhas, e o sítio do Pomar, no Arco da Calheta.

Esta barragem, localizada a 450 metros de altitude, manteve-se até Dezembro de 1939. No dia 30 desse mês as chuvas fortes provocaram a acumulação de grandes volumes de água, a que se seguiu uma enorme avalancha. $O$ forte declive do leito a jusante da secção obstruída contribuiu para acelerar o turbilhão de água, lama e rochas até ao mar, levando pela frente terrenos agrícolas, casas, animais, árvores e pessoas.

Embora sem causar tão graves danos como na Madalena, o temporal provocou estragos em vários pontos da ilha, como relatava a reportagem do "Diário de Notícias" de 31 de Dezembro de 1939:

- "Desde anteontem têm caído no Funchal e em toda a ilha abundantes chuvas, que causaram importantes estragos na agricultura.

As ribeiras que atravessam o Funchal trouxeram ontem grande caudal de água barrenta, o que era 
indício de derrocadas de terrenos pela corrente ao longo do seu percurso.

Pela tarde adiante as chuvas continuaram sem interrupção, chegando-nos notícia de vários danos e um desastre pessoal".

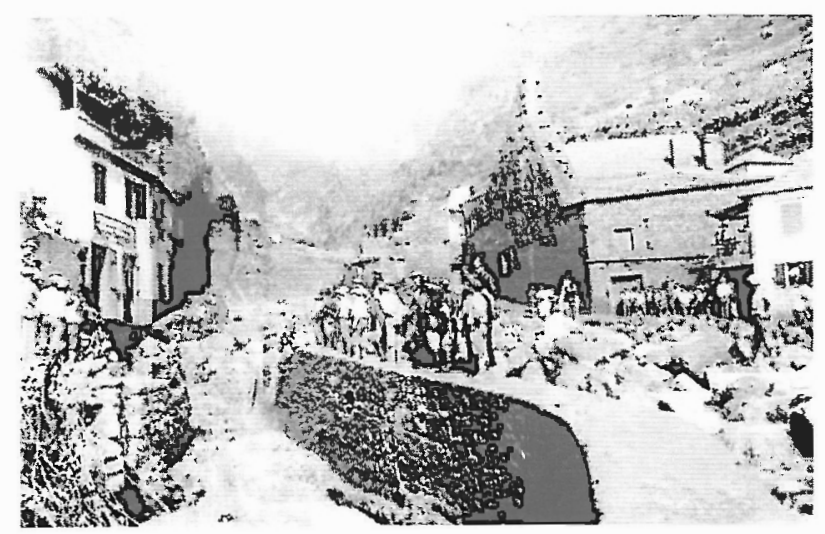

Ribeira da Madalena do Mar, um dia depois da cheia de 30 de Dezembro de 1939

(Foto: Perestrellos Photographos - Photographia - Museu "Vicentes")

14 e 15 de Outubro de 1945. - No Funchal várias ruas ficaram inundadas e os campos agrícolas foram bastante destruídos, mas foi outra vez na Madalena do Mar que as consequências do temporal de sudoeste se revelaram mais gravosas. No sítio da Banda d'Além 25 famílias, com cerca de 130 pessoas, perderam as suas modestas habitações.

"As chuvas torrenciais e o vento rijo fizeram destruições consideráveis, sobretudo em terrenos de cultivo, havendo árvores de fruto e bananeiras derrubadas, muros abatidos, casas com alguns destelhamentos, etc. Várias ruas apresentavam-se bastante inundadas dificultando o trânsito dos peões. Foi um dia de verdadeiro inverno, não obstante quente, com o tempo fixado no quadrante sudoeste.

Às primeiras horas da manhã, de ontem, o Funchal foi sobressaltado com a triste notícia de que na Madalena doMar se registara novo desastre, causando destruição de diversas pequenas casas.

E pelo dia adiante, as informações eram mais precisas: cerca de 25 casebres, na parte baixa daquela freguesia, no sítio da Banda d'Além, foram levados pela enxurrada da ribeira, ficando sem abrigo 25 casais, num total aproximado de 130 pessoas. Outras habitações estão sob a ameaça das águas caudalosas, incluindo a igreja paroquial que corre seriamente perigo". ${ }^{(15)}$
3 de Novembro de 1956. - Machico, Santa Cruz, Água de Pena, Porto da Cruz e Santo da Serra foram as localidades atingidas pela violência das águas. Estradas, pontes e casas destruídas; terrenos de cultivo e animais arrastados para o mar; 6 mortos.

"As freguesias do Porto da Cruz, Machico, Água de Pena e Santa Cruz foram ontem teatro de uma horrível tragédia. Repetiram-se, ali, as aluviões de 9 de Outubro de 1803 e 24 de Outubro de 1842.

As respectivas populações viveram horas de verdadeira angústia e natural pânico, aguardando o momento, que julgavam chegar, de serem arrastadas pela impetuosidade das águas. Eram cerca das 10 horas e 30 da manhã. Admite-se a hipótese de uma grande tromba de água ter caído na zona da Portela (...). Só assim se pode explicar o engrossamento imediato dos caudais das ribeiras e das inundações repentinas desta região."(16)

No Porto da Cruz foram destruídas quatro pontes. A enxurrada arrastou árvores de fruto, vimeiros e vinhas. Muitas vacas, porcos, cabras e ovelhas foram parar ao mar.

Em Machico registaram-se 3 mortos e ficaram várias pessoas feridas.

"A ponte que ligava o sítio do Piquinho ao Paraíso ficou destruída; o mesmo sucedendo com a da Ribeira Grande.

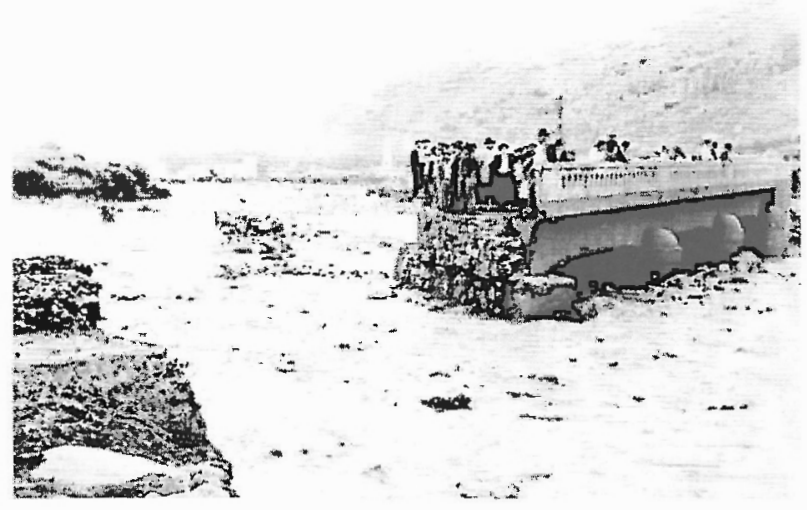

Ribeira de Machico - Ponte na estrada para o Caniçal, (Folo: Perestrellos Photographos - Photographia - Museu "Vicentes")

Quanto à Ponte Nova, na Estrada para o Caniçal, só existe a parte central, dado que os extremos foram arrastados pela enxurrada.

No sítio da Banda d'Além as águas que transpuseram as muralhas invadiram a capela dos Milagres. Registouse ali a inutilização da porta principal e o levantamento do soalho. As águas chegaram a atingir o altar. 


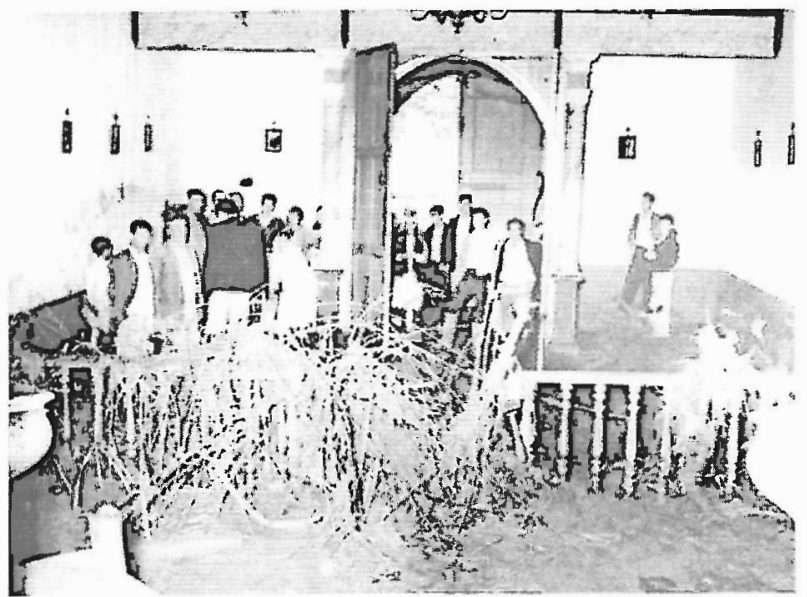

Interior da Capela dos Milagres - Machico.

(Foto: Perestrellos Photographos - Photographia - Museu "Vicentes")

Para dar uma ideia mais aproximada do que foi a terrível inundação bastará dizer que as águas chegaram a ultrapassar a altura dos telhados de alguns prédios" ${ }^{(17)}$

Na freguesia de Água de Pena, para além dos elevados prejuízos na agricultura, verificou-se a morte de uma criança, arrastada pelas águas lamacentas até ao mar, e a destruição da ponte do Seixo.

$\mathrm{Na}$ freguesia do Santo da Serra, o sítio da Ribeira de Machico foi o mais atingido. Ali morreu uma mulher, duas casas ficaram destruídas, vários palheiros desapareceram com a enxurrada, o mesmo acontecendo a sete vacas.

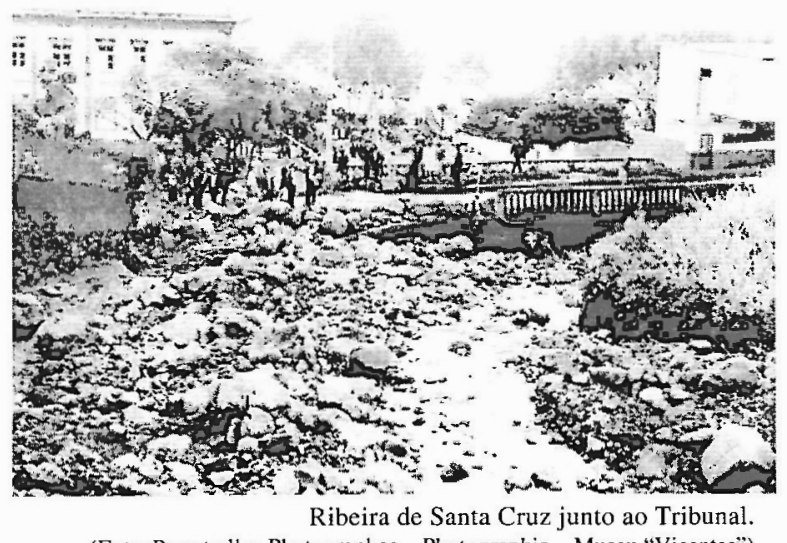

(Foto: Perestrellos Photographos - Photographia - Museu "Vicentes")

Em Santa Cruz as três pontes da vila foram parcialmente destruídas. A inundação atingiu a Igreja, o edifício da Santa Casa da Misericórdia e o prédio onde então funcionava a Câmara e o Tribunal. Uma criança foi tragada pelas águas torrenciais.
9 de Janeiro de 1970. - A ribeira Brava fez jus ao seu nome e destruiu em sete pontos a estrada entre a vila da Ribeira Brava e a freguesia da Serra de Água. O miradouro da vila desapareceu com a fúria das águas e com ele foram arrastadas para o mar duas pessoas, que nunca mais apareceram. Na Serra de Água, quatro pessoas morreram soterradas e várias casas foram destruídas.

"As chuvas torrenciais caídas durante o dia na zona da Serra de Água motivaram o aumento do caudal da ribeira a ponto do nível da água vir a atingir, no sítio da Ponte Vermelha, à entrada da vila da Ribeira Brava, a altura do piso da estrada marginal.

A situação piorou à medida que a tarde decorria e muitas foram as pessoas que se juntaram a ver o espectáculo devastador das águas, na estrada marginal da ribeira, junto à foz, e no miradouro ali existente, no extremo do jardim da vila. A violência das águas enlameadas, que corriam para o mar, trazendo galhos e árvores das zonas interiores, começou por destruir o campo de futebol da praia e arrancar as árvores plantadas na margem esquerda, entre a ponte e o miradouro.

Quando a própria estrada começou a ceder à força da corrente, os mais cautelosos afastaram-se, mas ainda algumas pessoas se encontravam no miradouro quando este ruiu, pouco antes das 19 horas". ${ }^{(18)}$

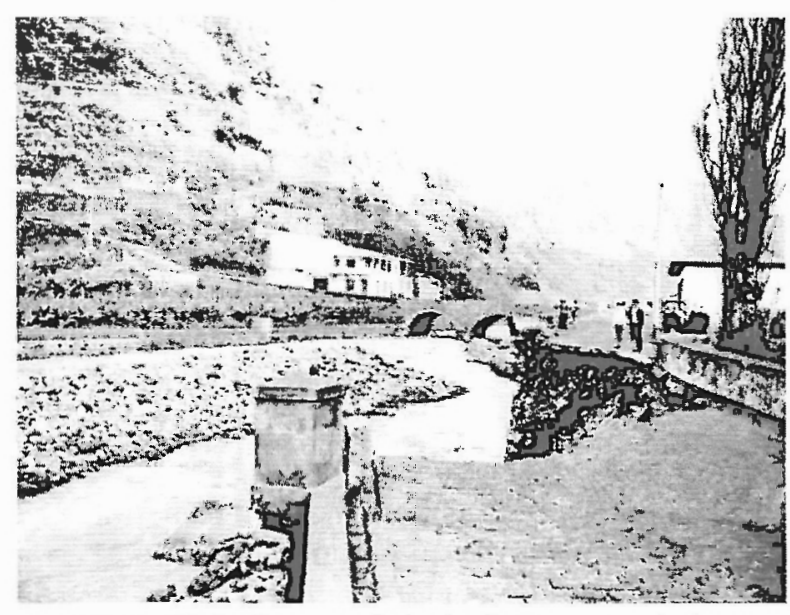

Vila da Ribeira Brava - a ribeira fez desaparecer o miradouro. (Foto: Carlos Fotógrafo - Photographia - Museu "Vicentes")

8 de Março de 1970. - Entre a meia noite e as $3 \mathrm{~h}$ e $30 \mathrm{~m}$, no Porto Santo ocorreu uma forte trovoada e choveu torrencialmente. Nesse período o udómetro localizado no aeroporto registou $77 \mathrm{~mm}$, dos quais $60 \mathrm{~mm}$ caíram em apenas 27 minutos.

"Entre os habitantes do Porto Santo não há memória de uma chuva tão torrencial em tão curto espaço de tempo. 
A chuva fez-se sentir com maior intensidade na vila, e no lado leste da ilha, tendo causado muitos estragosem paredes, culturas e estradas, nomeadamente a do Aeroporto, havendo zonas onde o próprio asfalto foi arrancado". (19)

Para além destes danos, as águas torrenciais provocaram a morte duma criança no sítio do Tanque.

21 de Setembro de 1972. - Pelas 4 da manhã, o caudal da ribeira de São João subiu repentinamente e estendeu-se muito para além do leito de estiagem, no sítio da Ribeira Grande, por baixo do campo de futebol do Marítimo. As águas arrastaram grandes blocos rochosos e destruiram parte dum bairro de lata que ali existia. Morreram 3 pessoas.

A humilde habitação donde foram arrastadas as três vítimas mortais localizava-se num sítio aparentemente seguro, cerca de 10 metros acima do nível onde habitualmente a água corre. Mas a ribeira de São João, em tempo de grossas chuvadas é imprevisível e catastrófica. Cerca de 50 metros a montante das barracas, a água galgou a margem esquerda e abriu com violência um novo caminho, levando tudo pela frente. Se mais pessoas não morreram foi porque a forte trovoada as fez levantar a tempo de fugirem à torrente arrasadora.

20 de Dezembro de 1977. - A precipitação atingiu no Funchal $70 \mathrm{~mm}$. Foram muitas as derrocadas nas zonas altas do Funchal, tendo uma provocado a morte de uma criança no sítio do Tanque, freguesia do Monte.

No Jardim da Serra uma "quebrada" obstruiu um ribeiro, que saiu do seu leito habitual e matou três mulheres.

Quarenta e cinco pessoas ficaram desalojadas em consequência das chuvas torrenciais.

20 a 24 de Janeiro de 1979. - Vento de Sudoeste com velocidade entre 40 e $50 \mathrm{Km} / \mathrm{hora}$, com rajadas que atingiram $70 \mathrm{Km} /$ hora; mar alteroso; fortes aguaceiros. Inundações, derrocadas, casas, pontes e caminhos destruídos em toda a ilha.

As chuvas "diluvianas começaram a cair cerca da uma hora e meia da madrugada de ontem - dia 20 e com uma maior intensidade entre as três e as quatro horas. Foi nesta ocasião que se verificaram assustadores caudais de água escoando pelas rochas abaixo e alimentando a torrente da Ribeira de Machico"(20), que correu um metro abaixo do tabuleiro da ponte de acesso à Banda d'Além.

Várias estradas municipais e pontes foram destruídas na Ribeira Grande e Maroços devido à subida do

(19) Diário de Notícias, Funchal, 9 de Março de 1970.

(20) Diario de Noticias, Funchal, 21 de Janeiro de 1979. caudal da ribeira. Naquele sítio, uma enxurrada destruiu duas habitações e matou duas pessoas.

"As veredas e córregos das áreas sobranceiras à sede do concelho transformaram-se em autênticos ribeiros, arrastando pedregulhos e outros detritos que atolharam as veredas e estradas principais, dum modo particular a E.N. 101 entre Machico e Porto da Cruz, onde se verificaram vários desmoronamentos e derrocadas".(21)

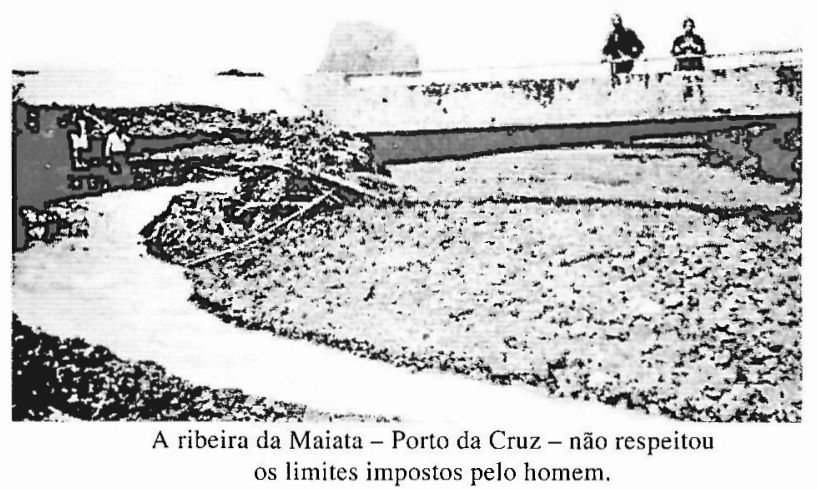

A freguesia do Porto da Cruz foi igualmente afectada pelas chuvas de forte intensidade. No sítio da Referta verificaram-se deslizamentos de solos e desmoronamentos de rochas, que provocaram a destruição de duas casas e a morte duma pessoa.

Na Camacha o mau tempo também causou uma vítima. Um homem de 78 anos sucumbiu entre as pedras e terras duma enxurrada que destruiu a parede traseira da sua casa.

Na zona oeste o temporal provocou muita destruição e morte.
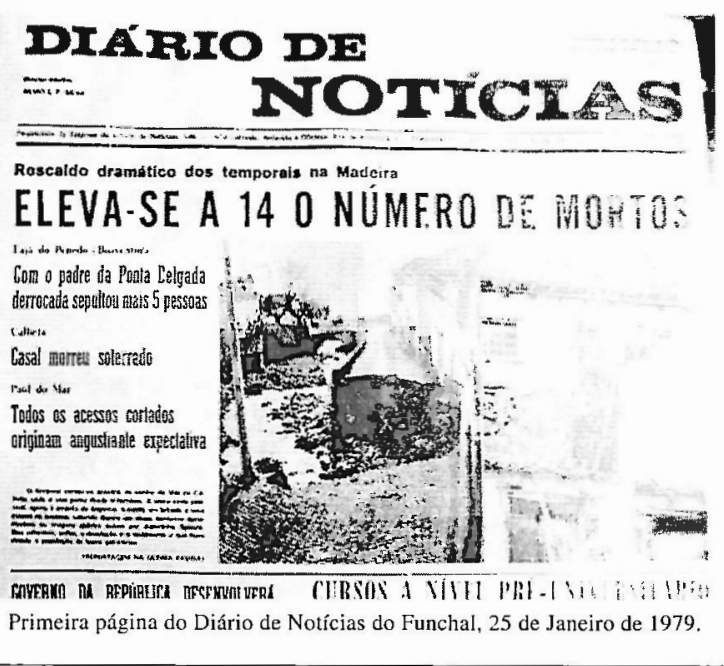

(21) Diário de Notícias, Funchal, 21 de Janeiro de 1979. 
Nafreguesia dos Canhas três casas foram destruídas por enxurradas, tendo, numa delas, falecido duas crianças.

A ribeira da Calheta invadiu a vila e deixou bastante danificada a rua principal. No sítio das Faias, uma avalancha de lamas e rochas soterrou uma residência e matou um casal.

O flagelo do mau tempo também atingiu o norte da ilha. Na Fajã do Penedo, Boaventura, na tarde do dia 23, um grande desmoronamento de terras, soterrou um automóvel e tirou a vida a 6 pessoas.

No balançodos 5 dias de temporal ficaram registados 14 óbitos.

1 e 2 de Março de 1984. - Chuvas intensas e ventos fortes provocaram derrocadas no sul e no norte da ilha.

Uma derrocada destruiu uma casa no sítio do Galeão, freguesia de São Roque. Um homem morreu arrastado pelas águas da Ribeira dos Socorridos.

A ponte do Faial desmoronou, tendo ficado isolado o nordeste da ilha. Construída em 1910, a ponte do Faial com 170 metros de comprimento, era então a mais extensa da Madeira. Alguns dos pilares que suportavam os seus sete arcos não resistiram à força das águas.

27 de Setembro de 1989. - A precipitação no Funchal foi de $97,7 \mathrm{~mm} ; 34,4 \mathrm{~mm}$ apenas em 60 minutos.

Inundações no Funchal, em Santa Cruze Machico.

18 de Setembro de 1990. - Entre as $14 \mathrm{~h} 05 \mathrm{~m}$ e as $14 \mathrm{~h} 45 \mathrm{~m}$ o Funchal esteve sob violenta trovoada e chuva forte.

Houve inundações em várias ruas e uma derrocada que provocou 2 mortos.

O desastre mais grave foi a queda de um muro da Rua da Penha de França sobre a Rua Carvalho Araújo que esmagou por completo um automóvel que ali circulava, provocando a morte instantânea dos seus dois ocupantes.

"Também na Rua das Fontes, paralela à Avenida do Mar, a chuva fez grandes estragos, quando em poucos minutos ficou totalmente inundada de água até um metro de altura. Os estabelecimentos comerciais da zona ficaram bastante afectados pela água, ao mesmo tempo que cá fora mais de uma dezena de automóveis estacionados ficavam autenticamente a boiar". (22)

Por incrível que pareça, quando no Funchal a violenta trovoada e a forte precipitação provocavam algum pânico, em Santa Cruz, na Ribeira Brava, no Ribeiro Frio ou em São Vicente o céu estava apenas pouco coberto.

(22) Diário de Notícias, Funchai, 19 de Setembro de 1989
Entre as $14 \mathrm{~h} 05 \mathrm{~m}$ e as $14 \mathrm{~h} 45 \mathrm{~m}$ o udómetro instalado no Observatório Meteorológico do Funchal registou uma pluviosidade de $37,8 \mathrm{~mm}$. No intervalo de 40 minutos caíram sobre a cidade quase 38 litros de água por metro quadrado.

Tanta precipitação em tão curto intervalo de tempo é um fenómeno bastante significativo e de consequências extremamente graves para as áreas onde ocorre. No entanto, não se trata duma situação muito rara no Funchal no mês de Setembro e nas proximidades da data do equinócio de Outono.

Segundo dados fornecidos pela Direcção Regional do Instituto de Meteorologia, entre 1951 e 1990 houve cinco registos de precipitação em Setembro com valores mais elevados do que em 18 de Setembro de 1990.

Quadro I - Valores máximos dá precipitação - Setembro

\begin{tabular}{|c|c|c|}
\hline ANO & DIA & Litros $/ \mathrm{m}^{2}$ \\
\hline 1962 & 22 & 49,1 \\
1972 & 21 & 72,6 \\
1982 & 16 & 42,1 \\
1984 & 22 & 73,2 \\
1989 & 27 & 97,7 \\
1990 & 18 & 38,2 \\
\hline
\end{tabular}

Foi a 27 de Setembro de 1989 que se verificou o maior valor absoluto da segunda metade do século $X X$. Nesse dia a precipitação durante vinte e quatro horas atingiu $97,7 \mathrm{~mm}$, dos quais $34,4 \mathrm{~mm}$ apenas $\mathrm{em}$ 60 minutos.

A 18 de Setembro de 1990 a altura da água no pluviómetrro não ultrapassou os $40 \mathrm{~mm}$, notando-se, no entanto, uma maior concentração dos aguaceiros que em 1989. Em apenas 40 minutos choveu 37,8 $\mathrm{mm}$. Esta diferença de concentração foi a principal responsável pelas consequências mais graves observadas em 1990.

Refira-se a propósito que não foi a primeira vez que os aguaceiros de Setembro provocaram mortes no Funchal. Na madrugada de 21 de Setembro de 1972, o caudal da Ribeira de São João aumentou repentinamente, invadiu um bairro de barracas localizado junto ao Campo da Imaculada Conceição em Santo António e retirou a vida a três pessoas.

Luto, consternação e depois o esquecimento. Mas o perigo das cheias e dos desmoronamentos continuou e continuará a espreitar. Todo o cuidado é pouco para impedir a morte e a destruição de bens aquando destas chuvas que surgem com alguma frequência na transição do Verão para o Outono.

Sempre que chove intensamente a comunicação social, fazendo eco das reacções populares, fala em trombas de água, mas diga-se em abono da verdade 
científica que não foi esse o fenómeno meteorológico que ocorreu no princípio da tarde de 18 de Setembro de 1990, nem na madrugada de 21 de Setembro de 1972.

Uma tromba de água é um turbilhão de vento, dum modo geral forte, com uma forma que lembra a tromba do elefante, que vem até a superfície do mar, provocando um forte efeito de sucção. Transporta grande quantidade de água para terra onde acaba por despejá-la numa área restrita.

As trombas de água aparecem em geral associadas a nuvens do tipo cúmulo ou cúmulo - nimbo.

A 18 de Setembro de 1990 o anfiteatro funchalense foi invadido por um cúmulo-nimbo, mas essa nuvem de forte desenvolvimento vertical não arrastava qualquer tromba de água. Se é verdade que as trombas de água se formam sempre na base de nuvens com desenvolvimento cumuliforme, não é menos verdade que essas nuvens só em casos esporádicos aparecem na zona onde se localiza a Madeira acompanhadas de tais apêndices.

Tive oportunidade de presenciar o fenómeno ocorrido no Funchal nesse dia e de analisar as cartas sinópticas de superfície e de altitude.

Um vale depressionário em altitude gerou forte instabilidade e um movimento convectivo do ar húmido. Formou-se uma nuvem em forma de torre, com a parte superior a fazer lembrar uma bigorna. Foi no seio desse cúmulo - nimbo que tiveram lugar os relâmpagos e os trovões que abalaram o Funchal, e foi ele que despejou sobre a cidade a água que correu pelas ruas e ribeiras, que invadiu as casas e estabelecimentos comerciais.

Depois da tempestade veio a bonança. A meio da tarde já o sol brilhava. Os cúmulo - nimbos são assim. Matam, destroem e desaparecem. Há que estar alerta, porque de tempos a tempos voltam a atacar.
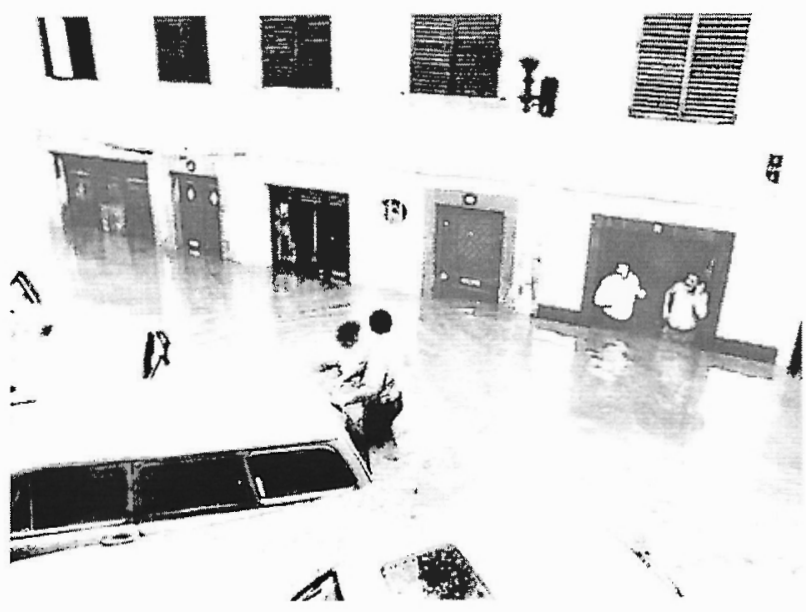

Rua das Fontes no Funchal às 15 horas de 18 de Setembro de 1990. (Foto: Arquivo do Diário de Notícias)
24 de Outubro de 1991. - Chuvas torrenciais, entre as 09 e as 13 horas, provocaram inundações em Machico. A ribeira subiu bastante mas não saltou as muralhas.

No Faial, Santana e Porto da Cruz também se verificaram derrocadas e inundações.

29 de Outubro de 1991. - Fortes chuvadas entre as 10 e as 11 horas da manhã.

Transbordaram ribeiros, pequenas pontes caíram, casas inundadas, estradas e automóveis destruídos.

No Funchal, mais uma vez o mar ficou castanho com as terras transportadas pelas ribeiras e na Barreirinha o desmoronamento dum muro pôs em perigo algumas habitações.

No Caniço, um ribeiro, abusivamente estreitado e coberto nalguns troços, abriu caminho através de algumas casas e invadiu a estrada de acesso à praia do Garajau, deixando-a em muito mau estado.

Em Machico, a água do ribeiro das Lajes saltou para a estrada municipal da Ribeira Grande que ficou intransitável. No sítio dos Landeiros, uma enxurrada destruiu parcialmente uma casa. A estrada regional entre Machico e Portela ficou interrompida devido a uma série de derrocadas.

29 de Outubro de 1993. - No Funchal, o udómetro localizado no Observatório Meteorológico registou uma precipitação de $88,9 \mathrm{~mm}$, entre as 09 horas do dia 28 e as 09 horas do dia 29. Choveu ao longo de todo dia 28 , mas foi entre as 21 e as 03 horas que se observou a grande descarga. Num período de 6 horas choveu 66,4 litros por $\mathrm{m}^{2}$, dos quais 29,8 entre as 02 e as 03 horas.

No Curral das Freiras, localizado na bacia de recepção da ribeira dos Socorridos, choveu 210 litros $/ \mathrm{m}^{2}$. O udógrafo do Instituto de Gestão da Água registou $37 \mathrm{~mm}$ entre as $01 \mathrm{e}$ as 02 horas, atingindo o pico de precipitação entre as 02 e as 03 horas com $38,8 \mathrm{~mm}$.

Com o aumento da altitude o valor da precipitação foi crescendo:

- Funchal (altitude: $58 \mathrm{~m}$ ) - 88,9 mm

- Trapiche (altitude: $500 \mathrm{~m}$ ) - 104,5 mm

- Santo da Serra (altitude: $660 \mathrm{~m}$ ) - 163,8 mm

- Curral das Freiras (Poiso - altitude: $750 \mathrm{~m}$ ) $210 \mathrm{~mm}$

As chuvas intensas na noite de 28 para 29 fizeram transbordar as três ribeiras que atravessam o Funchal (João Gomes, Santa Luzia e São João) e a ribeira dos Socorridos, no limite oeste do concelho.

Uma pluma castanha ocupou toda a baía e estendeuse muito para além da costa. A baixa citadina ficou coberta de lama, pedras e lenha. Vários armazéns destruídos, lojas comerciais arrasadas, estradas reben- 


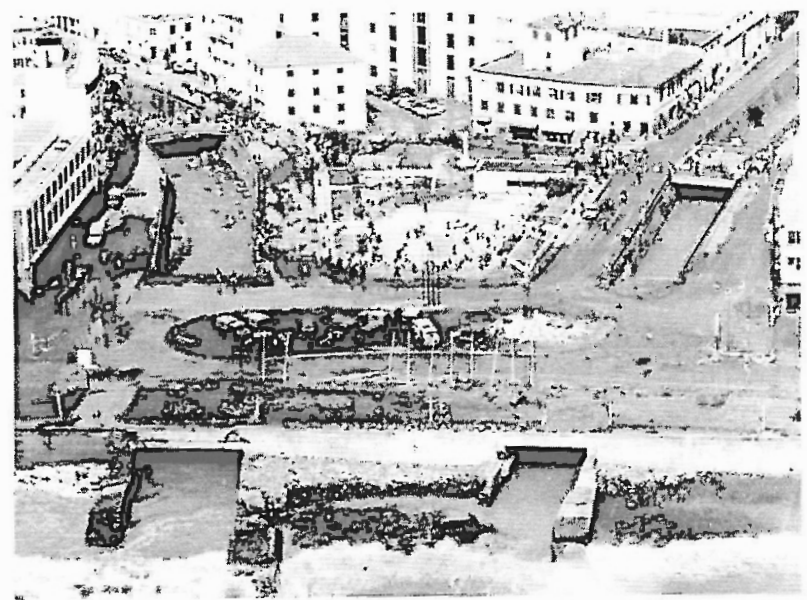

Com as embocaduras estranguladas peia Avenida do Mar. as ribeiras de Santa Luzia e João Gomes invadiram a Praça da Autonomia e a marginal, na madrugada de 29 de Outubro de 1993. (Foto: Rui Marote - Arạuivo do Diário de Notícias)

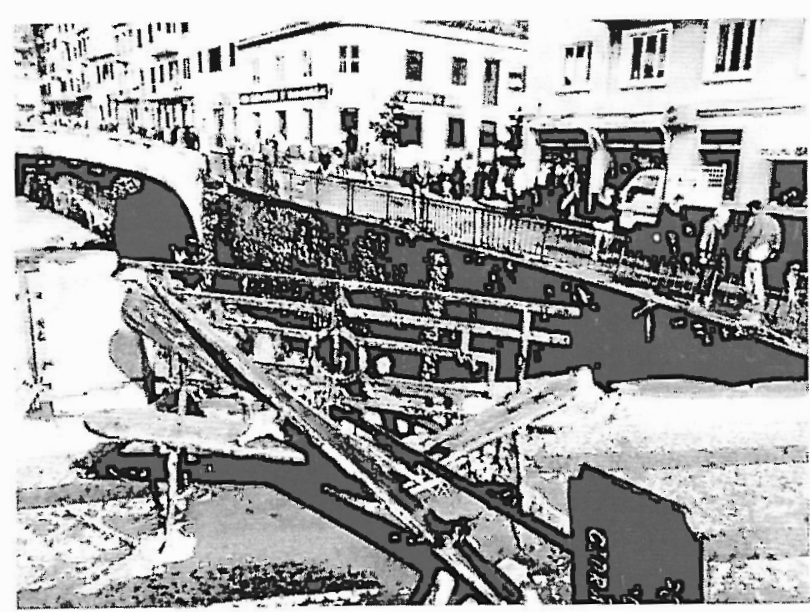

Ribeira de Santa Luzia, 100 metros a montante da foz. (Folo: Duarte Gomes - Arquivo do Jornal da Madeira)

tadas, falta de água potável durante quinze dias, uma escola destruída, 9 embarcações inutilizadas, muitos carros tragados pelas águas que sal taram as muralhas das ribeiras, 200 desalojados, cerca de 30 feridos, 9 mortos!

Os concelhos de Câmara de Lobos, Santa Cruz e Machico também foram bastante afectados pelo temporal, mas não se registaram mortes.

19 e 20 de Outubro de 1997. - A Madeira sofreu uma forte precipitação de 19 para 20.

No Curral das Freiras o udómetro do Instituto de Gestão da Água registou $349,9 \mathrm{~mm}$, entre as 09 horas do dia 19 e as 09 horas do dia $20, \operatorname{com} 52,5 \mathrm{~mm}$ das 19 às 20 horas. Entre as 20 e as 21 horas a chuva atingiu $40 \mathrm{~mm}$.
O pluviómetro do Laboratório Regional de Engenharia Civil, localizado no Chão do Areeiro (altitude: $1610 \mathrm{~m}$ ) recolheu $309,2 \mathrm{~mm}$. Entre as $18 \mathrm{e}$

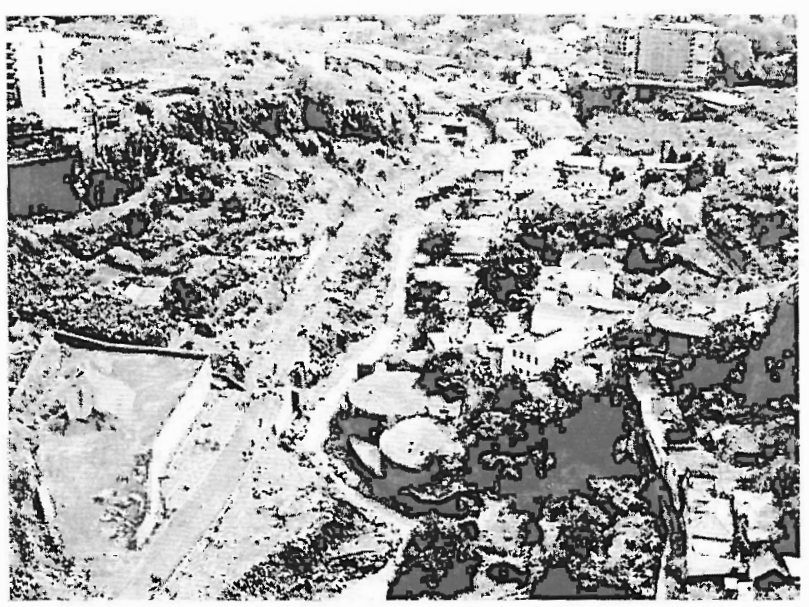

Vale da ribeira de São João, após a cheia de 29 de Outubro de 1993 (Foto: Agosiinho Spínola - Arquivo do Diário de Notícias)

as 19 horas, a precipitação chegou aos $36,6 \mathrm{~mm}$. Das 19 às 20 horas, a pluviosidade foi de $34,8 \mathrm{~mm}$.

Os caudais engrossaram imenso nas ribeiras dos Socorridos, São João, Santa Luzia, João Gomes e Machico, no sul, Juncal e Metade, no norte.

A destruição da ponte velha dos Socorridos e a queda da ponte de acesso à Estação de Tratamento de Agua dos Tornos, na ribeira de Santa Luzia, foram as consequências mais graves das cheias dessa noite.

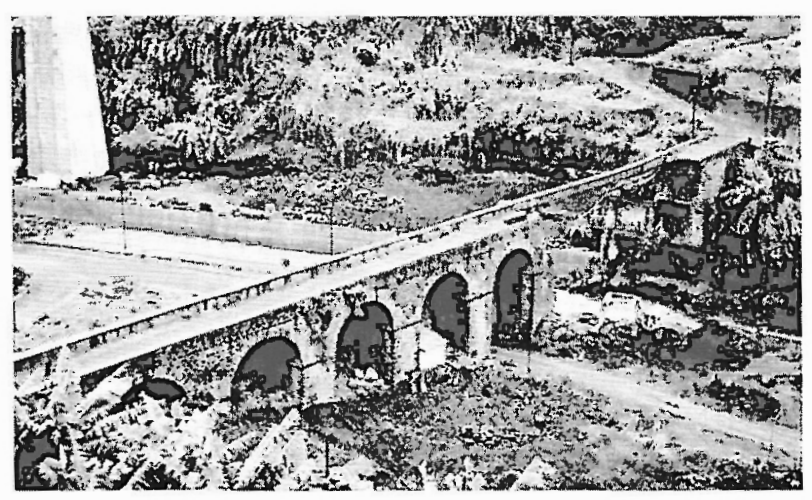

A ponte velha da ribeira dos Socorridos ficou parcialmente destruída na noite de 19 para 20 de Outubro de 1997.

$$
\text { (Foto: Raimundo Quintal) }
$$

Verificou-se também uma enorme acumulação de pedras e terras nos troços terminais das três ribeiras que atravessam a baixa do Funchal. A água só não saltou as muralhas, porque pouco tempo antes tinha sido feito o desassoreamento. 
1 de Fevereiro de 1998. - Durante a noite de 31 de Janeiro para 1 de Fevereiro choveu bastante no sul da ilha.

No Funchal, o Ribeiro Seco de São Gonçalo, que estava obstruído devido às obras dum viaduto da Via Rápida à cota 200, invadiu a estrada velha da Camacha e a estrada Conde Carvalhal. Foram muitas as casas inundadas, vários os carros arrastados, a lama chegou à Igreja de São Gonçalo.

No Caniço, junto ao Hotel D. Pedro Garajau, um pequeno ribeiro abusivamente manilhado rebentou com os limites que lhe foram impostos, invadiu ruas, inundou e encheu de lama muitas casas, arrasou parte das casas da Praia do Garajau. Este ribeiro já tinha causado bastantes estragos em 29 de Outubro de 1991.

No Garachico, Estreito de Câmara de Lobos, um escorregamento de terras, irresponsavelmente depositadas num talude, provocou a morte dum homem.

\section{Caracterização das condições atmosféricas que determinam as cheias}

De todas as aluviões descritas, a mais violenta foi a de 9 de Outubro de 1803. O "Elucidário Madeirense" caracteriza assim o estado do tempo que determinou essas cheias catastróficas:

"Tinham caído algumas chuvas, com várias intermitências, nos 10 ou 12 dias que precederam o 9 de Outubro de 1803. Neste dia, pelas 8 horas da manhã, começou a cair no Funchal uma chuva muito copiosa, que se manteve inalteravelmente até às 8 horas da noite, mas nada fazia recear que estivesse eminente uma tão terrível inundação. Principiou então a ouvir-se o ribombar do trovão e a chuva, acompanhada de algum vento, caía já em verdadeiras catadupas.

Às oito horas e meia, as águas das ribeiras galgaram as suas margens e espalhavam-se com grande ruído pelas ruas laterais, começando a sua obra de destruição e morte. Estava-se em pleno dilúvio". (23)

A não existência de registos meteorológicos impedenos de ter a certeza das situações sinópticas ocorridas. No entanto, ocruzamento deste texto com a informação contida nas duas cartas que trancrevemos aquando da descriçãoda aluvião de 1803 , permite-nos estabelecer uma analogia entre os estados da atmosfera que determinaram esse temporal e os que estiveram na origem das aluviões de 3 de Novembro de 1956, 20 a 24 de Janeiro de 1979 e 29 de Outubro de 1993.

As chuvas intensas e as trovoadas que ocorreram nesse fatídico dia de Outubro de 1803 devem ter sido provocadas pelo afluxo duma massa de ar tropical marítimo, vinda de sudoeste na circulação de uma depressão. Possivelmente a essa depressão estaria associado um sistema frontal.

(23) Elucidário Madeirense, I ${ }^{\circ}$ volume, página 52.
Às 00 horas do dia 3 de Novembro de 1956, a NW da Madeira havia um centro depressionário associado a um sistema frontal em cadeia, encontrando-se o arquipélago no sector frio anterior do mesmo. A noroeste da Grã Bretanha localizava-se um forte anticiclone que provocava, à latitude da Madeira, um afluxo de ar frio. $\mathrm{O}$ anticlone dos Açores estava repuxado para sul. Em virtude desta situação, fazia- se sentir na Madeira vento forte de SE, o céu estava encoberto e chovia. (Mapa 2).

A situação evoluiu rapidamente nas vinte e quatro horas seguintes. Às 00 horas do dia 4 a Madeira encontrava-se sob a acção dum fluxo de ar quente.

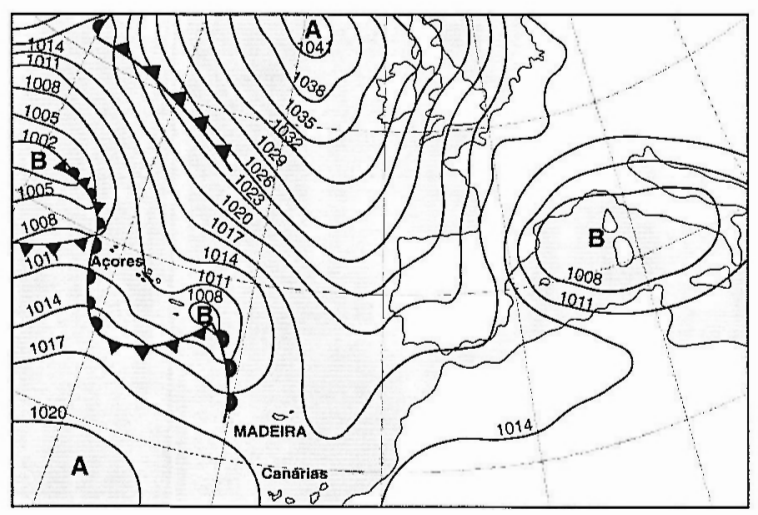

Mapa 2 - Carta de Superfície às 00 horas de 3 de Novembro de 1956

O sistema frontal evoluira, sofrendo uma retracção para norte, enquanto a oeste da Madeira se localizava um centro depressionário. $\mathrm{O}$ anticiclone a oeste das Ilhas Britânicas actuava como travão ao avanço das perturbações frontais para leste. (Mapa 3)

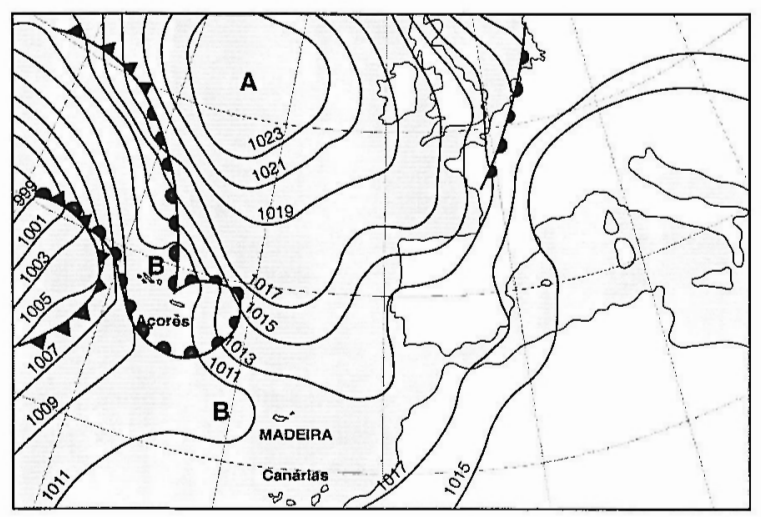

Mapa 3 - Carta de Superfície às 00 horas de 4 de Novembro de 1956

A evolução rápida e a passagem da frente fria originou forte pluviosidade, que atingiu proporções catastróficas na zona leste da ilha.

De 23 para 24 de Janeiro de 1979 o arquipélago da Madeira foi varrido por uma frente fria, que provocou as graves consequências já descritas anteriormente. 
Na noite de 18 para 19 a Madeira estava sob a influência do flanco sudoeste duma depressão bastante cavada, centrada na parte ocidental da Península Ibérica e reforçada por outra no norte da península. O céu encontrava-se pouco nublado e o vento era fraco.

Três dias mais tarde (noite de 21 para 22) uma série de depressões estendia-se a nordeste e a norte da Madeira. A noroeste localizava-se uma depressão mais cavada. A acção conjunta destes centros de baixa pressão e do anticiclone situado a sudoeste, originou um afluxo de ar marítimo quente e o estado do tempo piorou: vento forte, céu bastante nublado e precipitação.

Às 00 horas do dia 23 , à depressão que se localizava a noroeste associou-se um sistema frontal, encontrando-se já a Madeira no sector quente intermédio. A depressão era muito cavada; na Madeira, o céu encontrava-se muito nublado, o vento soprava forte de sudoeste e chovia intensamente. (Mapa 4)

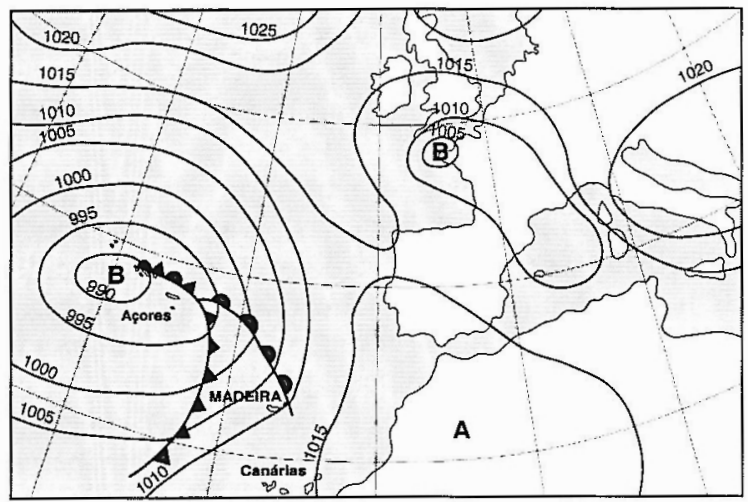

Mapa 4 - Carta de Superfície às 00 horas de 23 de Janeiro de 1979

Vinte e quatro horas mais tarde, o sistema frontal, que afectara todo o arquipélago, encontrava-se a leste deste, estando a Madeira sob a acção do sector frio posterior. O vento continuava muito forte de sudoeste, chovia intensamente e o céu estava muito nublado. (Mapa 5)

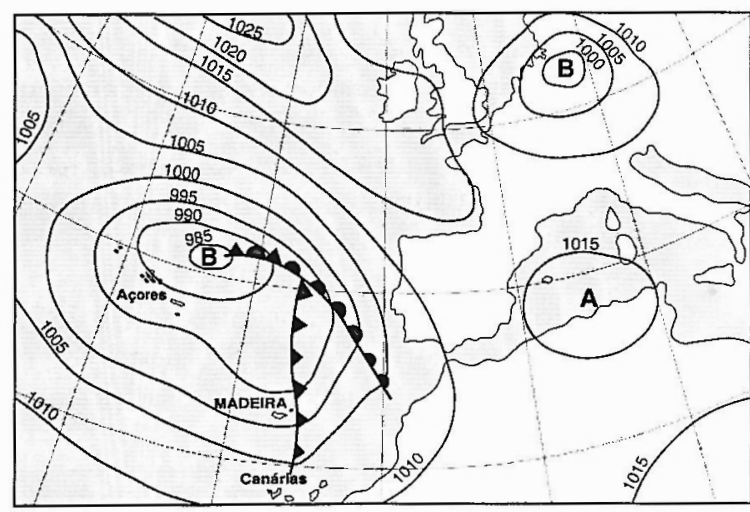

Mapa 5 - Carta de Superfície às 00 horas de 24 de Janeiro de 1979
A deslocação do sistema frontal para nordeste foi travada pelo anticlone que se localizava no Mediterrâneo ocidental e que no dia anterior se centrava sobre o noroeste do continente africano. Assim se explica a forte e prolongada pluviosidade verificada nestes dias na Madeira.

No dia 28 de Outubro de 1993, a Madeira começou a ficar sob a influência duma massa de ar quente e húmido, inserida na circulação duma depressãocentrada a sudoeste do arquipélago. (Mapa 6)

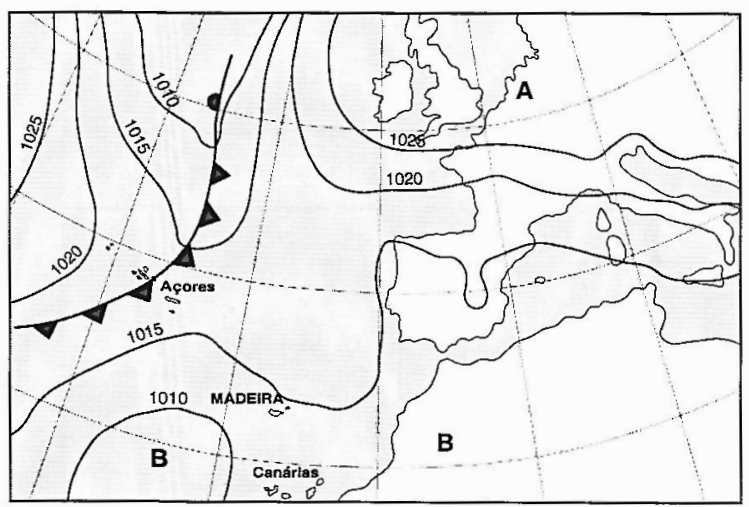

Mapa 6-Carta de Superfície às 00 horas de 28 de Outubro de 1993

Com o decorrer das horas, a pressão continuou a baixar e o centro ciclónico em deslocação lenta para nordeste atingiu a Madeira na madrugada do dia 29.

Vento, trovoada e chuva bastante forte foram os efeitos naturais da instabilidade da massa de ar, reforçada pelo efeito da orografia.

Choveu durante todo o dia 28 mas com pouca intensidade. Das 09 às 21 horas a precipitação totalizou $24,7 \mathrm{~mm}$. A partir das 21 a intensidade aumentou bastante, atingindo $29,8 \mathrm{~mm}$ entre as $02 \mathrm{e}$ as 03 horas do dia 29. (Mapa 7)

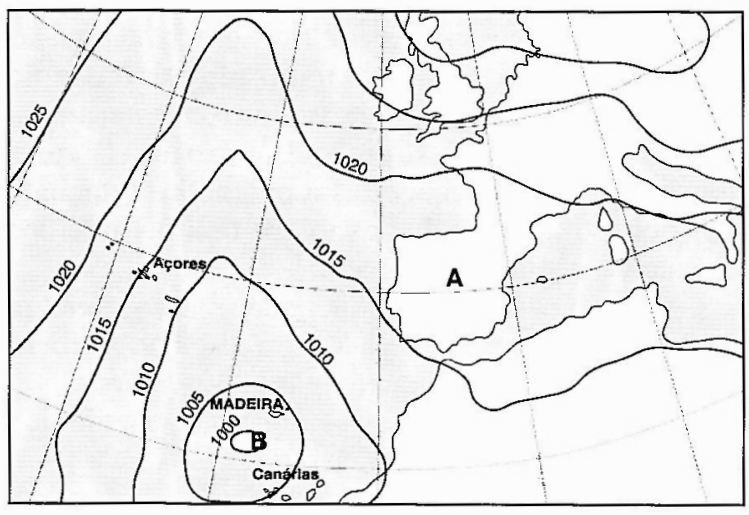

Mapa 7 - Carta de Superfície às 00 horas de 29 de Outubro de 1993

Após a passagem do "olho do ciclone" para norte da Madeira, a chuva praticamente terminou. 


\section{A distribuição mensal das cheias catastróficas}

Como ficou anteriormente descrito, desde o início do século XIX até 1998 registaram-se 30 aluviões, sendo 8 no século XIX e 22 no século XX.

As aluviões do século XIX verificaram-se em Janeiro (2), Março (1), Outubro (4) e Novembro (1).

No século XX a distribuição mensal foi a seguinte: Janeiro (2), Fevereiro (2), Março (4), Setembro (3), Outubro (6), Novembro (2), Dezembro (3).

No período estudado a distribuição mensal das aluviões ficou ordenada como se pode observar no Quadro 2.

Quadro 2 - Aluviões. Séculos XIX e XX

\begin{tabular}{|c|c|}
\hline$M \hat{E} S$ & Número de Aluviões \\
\hline Janeiro & 4 \\
Fevereiro & 2 \\
Março & 5 \\
Setembro & 3 \\
Outubro & 10 \\
Novembro & 3 \\
Dezembro & 3 \\
TOTAL & 30 \\
\hline
\end{tabular}

Estes números deixam transparecer que o Outono é a estação mais atreita à ocorrência de cheias catastróficas, ocupando o mês de Outubro uma posição muito destacada.

O sul, apesar de ter um clima mais quente e menos chuvoso é mais afectado pelas aluviões, o que se explica pelo facto das chuvas torrenciais - que provocam os deslizamentos de solos, derrocadas e caudais lamacentos - serem determinadas pela ascensão rápida de massas de ar quente e húmido impelidas pelos ventos de sudoeste ou, mais raramente, de sul. O movimentoconvectivo, gerado no seio das depressões e pela passagem das frentes, é reforçado pela orografia.

A maior pressão demográfica na parte meridional da ilha provocou a destruição da cobertura florestal das montanhas sobranceiras à cidade do Funchal e aos outros núcleos urbanos, o que tem favorecido a erosão e a rápida escorrência.

A aluvião com consequências mais graves no norte da ilha ocorreu a 6 de Março de 1929. A ribeira da Vargem em São Vicente matou 32 pessoas.

No Porto Santo apenas se registou uma aluvião, precisamente no dia 8 de Março de 1970.

Das 22 aluviões registadas este século, 14 ocorreram na segunda metade, sendo 13 a partir de 1970. Serão estes factos reveladores duma alteração no clima do arquipélago? Ou duma crescente impermeabilização dos solos e ocupação dos leitos de cheia?

\section{Condições que favorecem as Aluviões}

Em 19 de Fevereiro de 1804 chegou à Madeira o Brigadeiro Reinaldo Oudinot, reputado especialista em engenharia, que veio com a missão de dirigir os trabalhos de recuperação dos estragos provocados pela grande aluvião e orientar a construção das muralhas laterais das ribeiras.

A 23 de Setembro de 1804 desembarcou no Funchal Paulo Dias de Almeida, Tenente Coronel do Real Corpo de Engenheiros, que veio colaborar com o Brigadeiro Oudinot.

Em Dezembro de 1806, após mais uma aluvião, "o Brigadeiro Oudinot podia escrever ao Visconde de Anadia, dando conta da forma positiva como se tinham portado as suas obras. Efectivamente, oencanamento das três ribeiras do Funchal que ainda temos hoje, em linhas gerais, éobra do Brigadeiro Oudinot". (24)

Mas se em 1806 o Brigadeiro Oudinot manifestara o seu regozijo pelo facto das novas muralhas terem impedido que as águas revoltas invadissem as ruas do Funchal, em 1817 Paulo Dias de Almeida apontava o dedo acusador às causas que estiveram na origem da aluvião de 1815:

"O centro da ilha se acha todo descoberto de arvoredo, com apenas algumas árvores dispersas, e isto em lugares onde os carvoeiros não têm chegado. Se tivessem posto em execução as Ordens e Cartas Régias relativas à conservação dos arvoredos, não teriam a cidade e as vilas sofrido os estragos da memorável aluvião de 1803 . A experiência tem mostrado que a falta de arvoredos pelas margens das ribeiras e declives dos montes que sobre elas desaguam, é a causa da imensidade de rocha e terra que com as chuvas vem atulhando as mesmas ribeiras, cujo álveo, hoje está superior às ruas da cidade. A praia do Funchal, se tem alongado ao mar, desde 1803 até 1817,150 palmos e em partes 250 e mais, com os entulhos que as ribeiras depositam.

Em 30 de Outubro de 1815 pelas 5 horas da tarde, houve uma aluvião que levou quarenta casas e arruinou outras, inundando ruas, e se fosse à noite muita gente morreria afogada. A ribeira de São Paulo chegou a trazer uma coluna de água e rochedos, que ocuparam a largura de 60 palmos e 30 de alto. Entre as pedras que ficaram no leito da ribeira, junto ao mar, havia uma de 20 palmos quadrados, e de 10 palmos muitas. A enchente durou uma hora". (25)

Governador Civil da Madeira entre 1846 e 1852, o Conselheiro José Silvestre Ribeiro desenvolveu em poucos anos uma notável luta contra a desertificação das serras madeirenses.

(24) Rui CARITA, Paulo Dias de Almeida e a Descrişão da llha da Madeira, Funchal, 1982, página 25

(25) Idem, páginas 53 e 54. 
Cabe aqui recordar que os lombos e vertentes escalvados contribuiram de forma decisiva para o volume de materiais carreados até ao mar nas aluviões de $1803,1815,1842$ e 1848.

$\mathrm{Na}$ correspondência com as Câmaras é possível detectar a sua apreensão pelo estado calamitoso em que se encontravam as Serras da Madeira, não se eximindo mesmo de criticar com veemência os gestores municipais como se pode perfeitamente ver, por exemplo, na carta enviada aos Administradores de Concelho em 28 de Fevereiro de 1850. Dessa missiva vale a pena respigar algumas frases bastante esclarecedoras: - "Quem está à frente dos negócios administrativos da Madeira não pode um só momento perder de vista a arborização das suas Serras, e a indispensabilidade de providenciar que se conservem religiosamente as matas que ainda existem, e se plantem novas nos sítios onde a devastaçãofunestíssima de longos tempos tem chegado. Quantos inimigos se não conjuram contra o arvoredo? Aqui os lenheiros e carvoeiros; além os criadores de cabras e por ventura de outro gado; acolá os curtidores de peles, fazendo uso da casca do Vinhático e do Aderno para aquele mister; por um lado a indolência e o descuido das Autoridades; por outro a falta de perseverança dos proprietários; e finalmente a impunidade dos devastadores". ${ }^{(26)}$

Aquele Governador Civil era um homem culto, que não se limitava a fazer críticas. Indicava remédios para as doenças que atormentavam as ilhas deste arquipélago, nunca cruzando os braços. Ordenava às câmaras o maior cuidado na conservação das árvores existentes nas "bordas das fontes, e em fazer plantar em todos esses pontos Vinháticos, Tis, Loureiros, Adernos. Perados e outras árvores quaisquer, que sejam próprias para atrair e conservar a humidade, e alimentar os cabedais das nascentes". (27)

E para que estas medidas não morressem no papel, defendia que as Câmaras deveriam imediatamente arborizar os terrenos que lhes pertenciam, bem como criar viveiros aptos a fornecer plantas a todos os solos carentes de revestimento florestal. Os donos dos terrenos particulares deveriam, também, ser responsabilizados pela nobre tarefa de plantar árvores onde estas fossem necessárias e de conservar a floresta, sugerindo mesmo a criação de prémios para galardoar aqueles proprietários que mais se distinguissem nessa tarefa.

Infelizmente o diagnóstico feito há mais de um século por José Silvestre Ribeiro, mantém-se nas linhas gerais bastante actual. O carvão deixou de ser fonte de energia e a lenha é hoje incomparavelmente menos usada pelos madeirenses. Mas o gado caprino e ovino

(26) Sérvulo Drummond de MENESES e António Jacinto de FREITAS, Uma Época Administrativa da Madeira e Porto Santo, Funchal, 1850-52. (27) Idem, 1850-52. continua a vaguear livremente pelas altas montanhas, delapidando toda a vegetação espontânea, teimando em manter as serras escalvadas, e os fogos florestais fazem a sua aparição sempre que a atmosfera se aquece e desumidifica com a chegada do vento de leste.

Nas cabeceiras nuas das ribeiras começam as cheias catastróficas. A ascensão rápida de massas de ar quente e húmido nas vertentes voltadas a sul gera chuvas concentradas, que, na falta dum anteparo florestal, atingem com forte impacto os solos indefesos. Terras e rochas são arrastadas vertente abaixo, concentrando-se nos vales das ribeiras principais, que descem dos 1600 metros até ao mar em menos de $10 \mathrm{Km}$. Tudo isto ocorre muito rapidamente. As bacias de recepção são pequenas e respondem quase de imediato às chuvas torrenciais.

Em poucas horas, ocaudal lamacento, carregando enormes blocos rochosos, leva para o oceano os terrenos de cultivo e as construções instaladas nas margens do canal de escoamento.Quando a cheia coincide com a preia-mar e com ondas alterosas, a foz fica obstruída num curto lapso de tempo e o risco de inundação é maior.

$\mathrm{E}$ quanto mais comprimidas são as margens e destruídos os meandros naturais, maior é a energia destruidora das águas que descem das montanhas. Na noite de 29 de Outubro de 1993, as ribeiras que sulcam o Funchal voltaram a manifestar-se, desmentindo de forma categórica os que julgavam que o betão era capaz de domar o carácter torrencial dos cursos de água madeirenses.

\section{Que fazer para minimizar os efeitos das Aluviões?}

No dealbar do século XXI continuam pertinentes as soluções apontadas por José Silvestre Ribeiro com o propósito de diminuir o ímpeto das aluviões e aumentar as reservas hídricas.

Acabar com o pastoreio nas altas montanhas e fazer renascer a formação arbustiva típica desse biótopo, são condições necessárias para começar a estancar na origem a delapidação dos solos, tão imprescindíveis nos vales e cristas interfluviais da cordilheira central, como indesejáveis nos fundos dos mares costeiros.

Dos 1400 metros até aproximadamente aos 600 metros de altitude - onde faltam as árvores ou onde os eucaliptos e as acácias impuseram ditaduras monoculturais após a desvalorização da lenha como fonte energética - devem ser envidados todos os esforços com o objectivo de fazer retornar as variadas espécies de árvores, arbustos e pequenas plantas integrantes da Laurissilva. A recuperação da floresta indígena, para além dos benefícios no domínio da 
biodiversidade, garantirá uma maior infiltração de água e uma mais eficaz protecção dos solos. Mais Laurissilva significará menor risco de aluvião.

Para minimizar os efeitos das cheias é igualmente necessária uma gestão cuidada dos canais de escoamento, quer nas áreas rurais, quer nas zonas urbanas. $\mathrm{O}$ facto das ribeiras e ribeiros apresentarem estiagens prolongadas provoca um atrevimento exagerado por parte das populações, empresas e até das entidades que têm a responsabilidade de gerir os cursos de água.

Continua-se a encanar as ribeiras, transformandoas em apertados canais, substituindo os meandros redutores de energia por travessões, que rapidamente ficam assoreados e perdem parte significativa da projectada eficácia.

Explorações agrícolas, habitações, armazéns, unidades industriais e até centrais eléctricas têm continuadoa serinstaladas nos leitos de cheia, deixando um estreito caminho para a água se dirigir até ao mar.

E para complicar a passagem da água, as fozes de algumas ribeiras estão cobertas por estradas. O risco é tanto maior se os leitos estiverem assoreados e forem usados como vazadouros de terras, entulhos e lixos.

Por isso, todos os anos, antes do equinócio de Setembro, têm de ser realizados grandes trabalhos de desassoreamento nos troços próximos das desembocaduras das ribeiras, para evitar que as águas das chuvas torrenciais do Outono saltem os muros de protecção.

Mesmo assim, ninguém com bom senso poderá afirmar que uma aluvião catastófica não voltará a acontecer.
BIBLIOGRAFIA:

BATEIRA, C., RESENDES, J. e REBELO, F. (1998) - "Escoamento torrencial e processos geomorfológicos na Bacia da Povoação (S. Miguel, Açores). As cheias de 14 de Dezembro de 1996", Territorium 5, p. 5-24.

CARVALHO, A. M.Galopim de, e BRANDÃO, José M. (1991) Geologiado Arquipélago da Madeira, Lisboa, Museu Nacional de História Natural, Lisboa.

DONN, William L. (1978) - Meteorologia, Barcelona, Reverté.

CHASCO, C. Ferreras e HIJANO, C. Fidalgo (1991) - Biogeografía y Edafogeografia, Madrid, Sintesis.

GAGEL, C. (1969) - Estudo sobre a estrutura e as rochas da Madeira, Lisboa, Centrode Estudos de Geologia da Faculdade de Ciências de Lisboa.

PIGEON, Patrick (1995) - Ville et environnement, Paris, Nathan.

QUINTAL, Raimundo e VIEIRA, Maria José (1985) - Iha da Madeira - Esboço de geografia física, Funchal, Secretaria Regional do Turismo e Cultura.

REBELO, Fernando (1997) - "Risco e crise nas inundações rápidas em espaço urbano. Alguns exemplos portugueses analisados a diferentes escalas", Territorium, 4, p. 29-47.

RIBEIRO, Orlando (1985) - A Ilha da Madeira até meados do século $X X$, Lisboa, Instituto de Cultura e Língua Portuguesa.

SÁNCHEZ, Luis Albentosa (1991) - El clima y las aguas, Madrid, Sintesis.

SANJAUME, María Sala, e VILLANUEVA, Ramon J. Batalla (1996) - Teoria y métodos en Geografía Física, Madrid, Sintesis.

SUMMERFIELD, Michael A. (1991) - Global geomorphology, Essex, Longman Scientif \& Technical.

TARBUCK. E. J., e LUTGENS, F. K. (1992) - The earth - an introduction to physical geology, New York, Macmillan. 